

November 8 to November 27

$\varnothing$

At the Galleries of

E. GIMPEL $ซ$ WILDENSTEIN

647 FIFTH AVENUE, NEW YORK 


\section{Catalog of the Exhibition}

BOARDMAN ROBINSON.

1 Samson and Delilah.

2 Two Prisoners-Russia, 1915.

3 The Hands of Moses.

F. G. R. ROTH.

4 Polar Bear and Cubs.

C. C. RUMSEY.

5 Garden Figures.

ELMER SCHOFIELD.

6 Landscape.

JOHN SLOAN.

7 Bleecker Street Saturday Night.

8 Moonlight Calle San Francisco Santa Fe.

9 The Range-Autumn.

\section{EUGENE SPEICHER.}

10 Portrait of Katherine.

11 Landscape.

12 Flower Piece.
MAURICE STERNE.

13 Portrait Bust.

ALBERT STERNER.

14 Life Passes.

15 Portrait of Dr. Richard Horace Hoffman.

16 The Passion.

EDMUND C. TARBELL.

17 Mary Edmund and Sergius II.

GERTRUDE VANDERBILT WHITNEY.

18 Spirit of the Red Cross.

19 Honorably Discharged.

IRVING R. WILES.

20 Souvenirs.

MAHONRI YOUNG.

21 Cecilia Sharp Young.

22 Navajo Woman and Goats.

23 The Young Kid.

24 Drawing.

25 Drawing. 
CHESTER BEACH.

26 Portrait of Madison Grant.

27 "Breath of the Pines."

GIFFORD BEAL.

28. Hunters and Hounds.

29 Landscape.

\section{REYNOLDS BEAL.}

30 Beach Ponies.

31 The Band Wagon

\section{GEORGE BELLOWS.}

32 Eleanor, Jean and Anna.

ROBERT W. CHANLER.

36 Phantasy.

TIMOTHY COLE.

37 Portrait.

\section{PAUL DOUGHERTY.}

38 St. Jean de Luz.

39 Path in the Woods.

HUN'T DIEDERICH.

40 Faun.

RANDALL DAVEY.

41 Early Morning, Walpi, Arizona.

42 Man in the Hills.

43. Indian Thunder Dancer.

GUY PENE DU BOIS.

44 Figures.

45 First Pose.

JOHN FLANAGAN.

46 Head of Walt Whitman.

47 War Medal for Marion, Mass.

JAMES EARLE FRAZER.

48 Portrait of $O$.

49 Mask.

FREDERICK C. FRIESEKE.

50 "Peace."

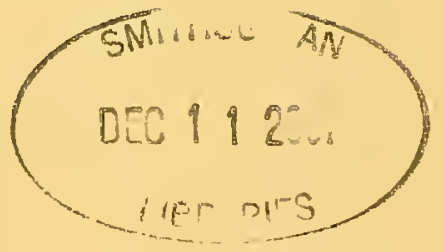


WIILIAM J. GLACKENS.

51 Portrait.

52 Study.

IVALTER GRIFFIN.
53 Landscape.
54 Landscape.

SAMUEL HALPERT.

55 Summer.

56 Gladioles.

CHILDE HASSAM.

57 July Night.

58 Peony Girl.

59 Central Park 1890.

ROBER'T HENRI.

60 Celestine.

61 Chinese Jacket.

\section{ROCKWELL, KENT.}

62 Snow Fields.

63 Indian Summer, Alaska.

64 Fire Wood.

65 The Day's Work.
LEON KROLL.

6б Portrait of M. Jules Antoine Guillaume.

67 August Day.

GASTON LACHAISE.

68 Portrait.

69 Woman.

ERNEST LAIVSON.

70 Snowbound.

71 Hillside Farm.

HAYLEY LEVER.

72 Studio Garden.

73 Harbor.

JONAS LIE.

74 Hope.

GEORGE LUKS.

75 A Flapper.

PAUL MANSHIP.

76 John Barrymore. 
DODGE MACKNIGHT.

77 Gypsy Cave, Spain.

78 Off for a Good Time.

HENRY L. MCFEE.

79 Portrait of a Painter.

80 Landscape.

GARI MELCHERS.

81 Winged Victory.

82 Supper at Emmaus.

A. JEROME MYERS.

83 The Angels of the Festa.

84 The Park Concert.

85 Study.

86 Recreation.

87 Prints.

ELIE NADELMAN.

88 Woman Seated.

89 Nude.

90 Nude.

91 Head.

\section{ANDREW O'CONNOR.}

92 Composition.
JOSEPH PENNELL.

93 The Alley.

94 Christ Church.

95 Independence Square.

96 St. Peter's Graveyard.

97 St. Peter's, 4th and Pine Streets

98 From League Island.

99 Old Philadelphia.

100 Second and Market Streets.

101 From Belmont.

102 Broad Street.

103 Girard Street, No. 1.

104 Girard Street, No. 2.

105 Stock Exchange.

106 Water Works.

\section{VAN D. PERRINE.}

107 Autumn Landscape.

108 Spring Morning.

109 Chalk Drawings.

MAURICE B. PRENDERGAST.

110 Late Summer Afternoon.

111 October Day.

112 The Beach.

EDMOND T. QUINN.

113 Blasco Ibañez.

114 The Scotchman Abroad.

115 William Jean Beanley.

116 Leon Gordon.

117 On the Summit. 


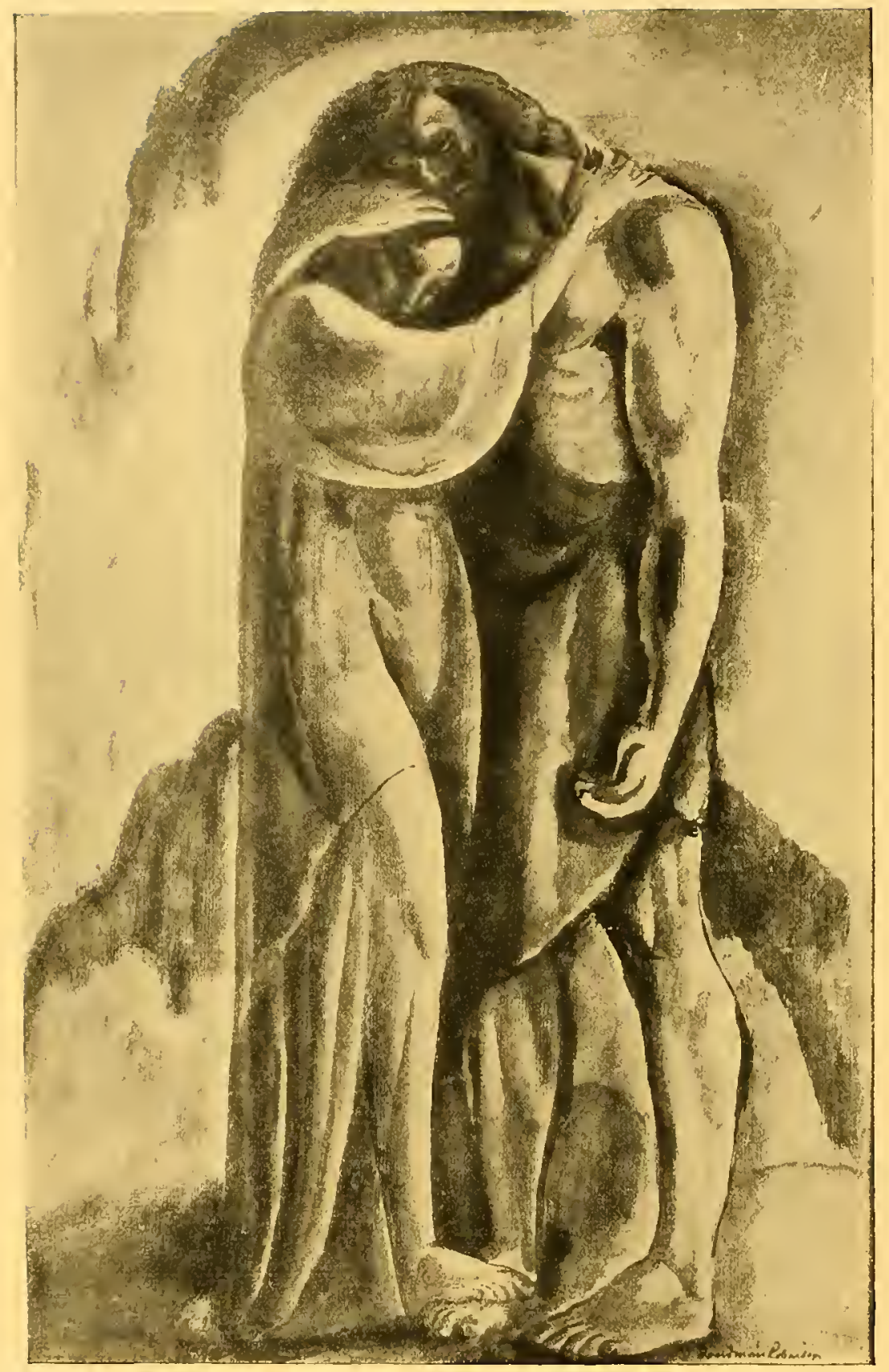

Samson and Delilah by Boardman Robinson

8. 


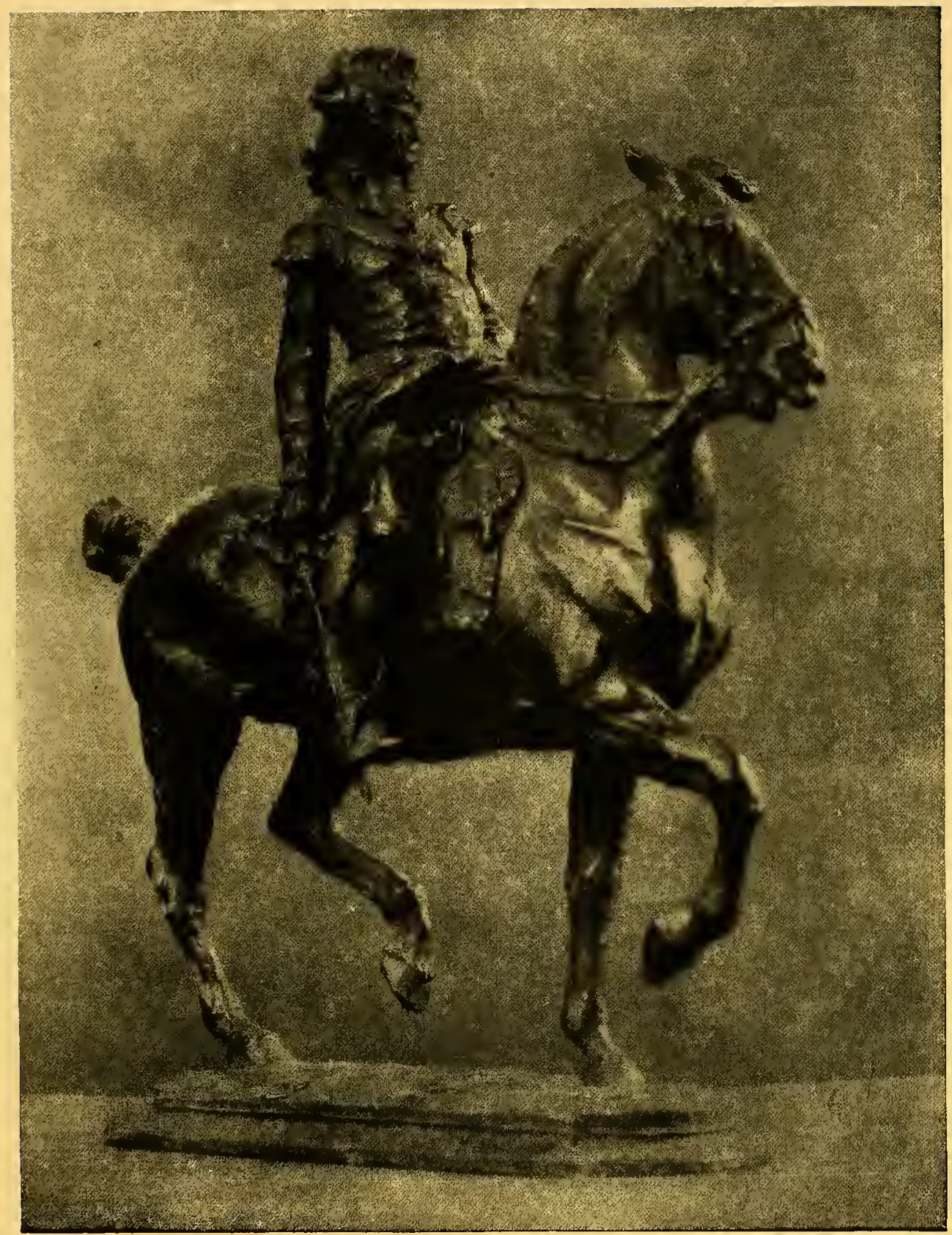

Colonial General by F. G. R. Roth 


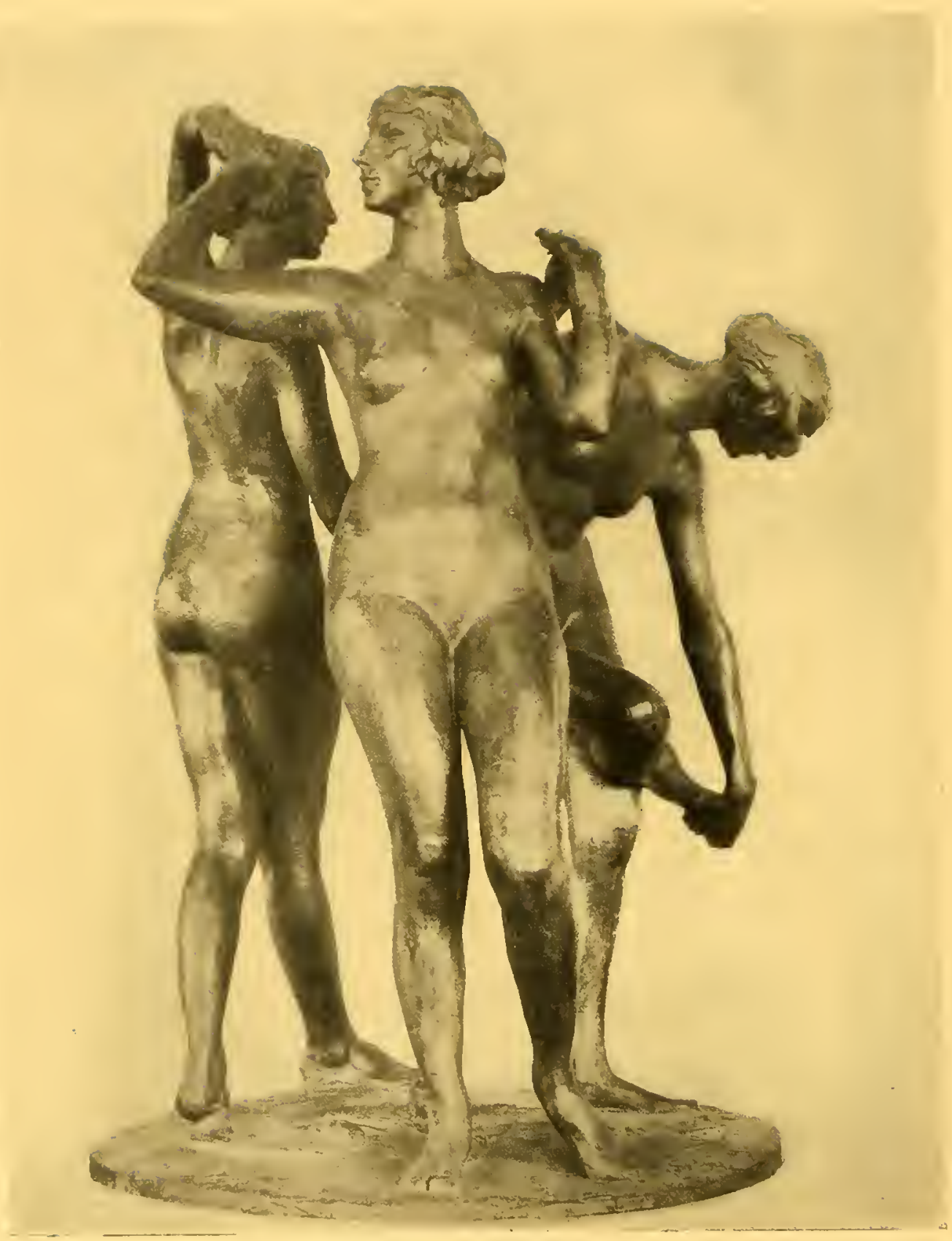

Fountain Figures by C. C. Rumsey 


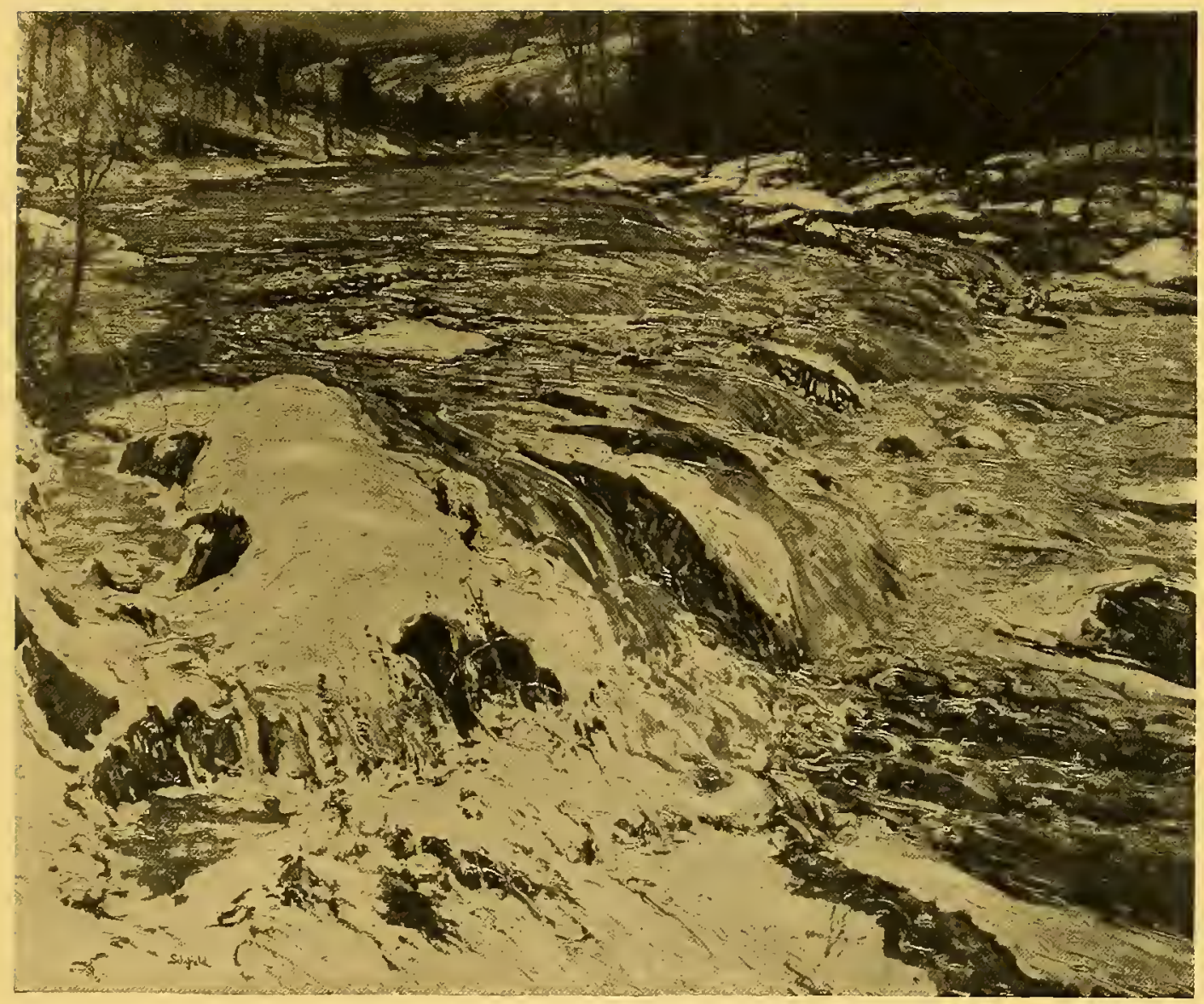

Bend in the River by Elmer Schofield 


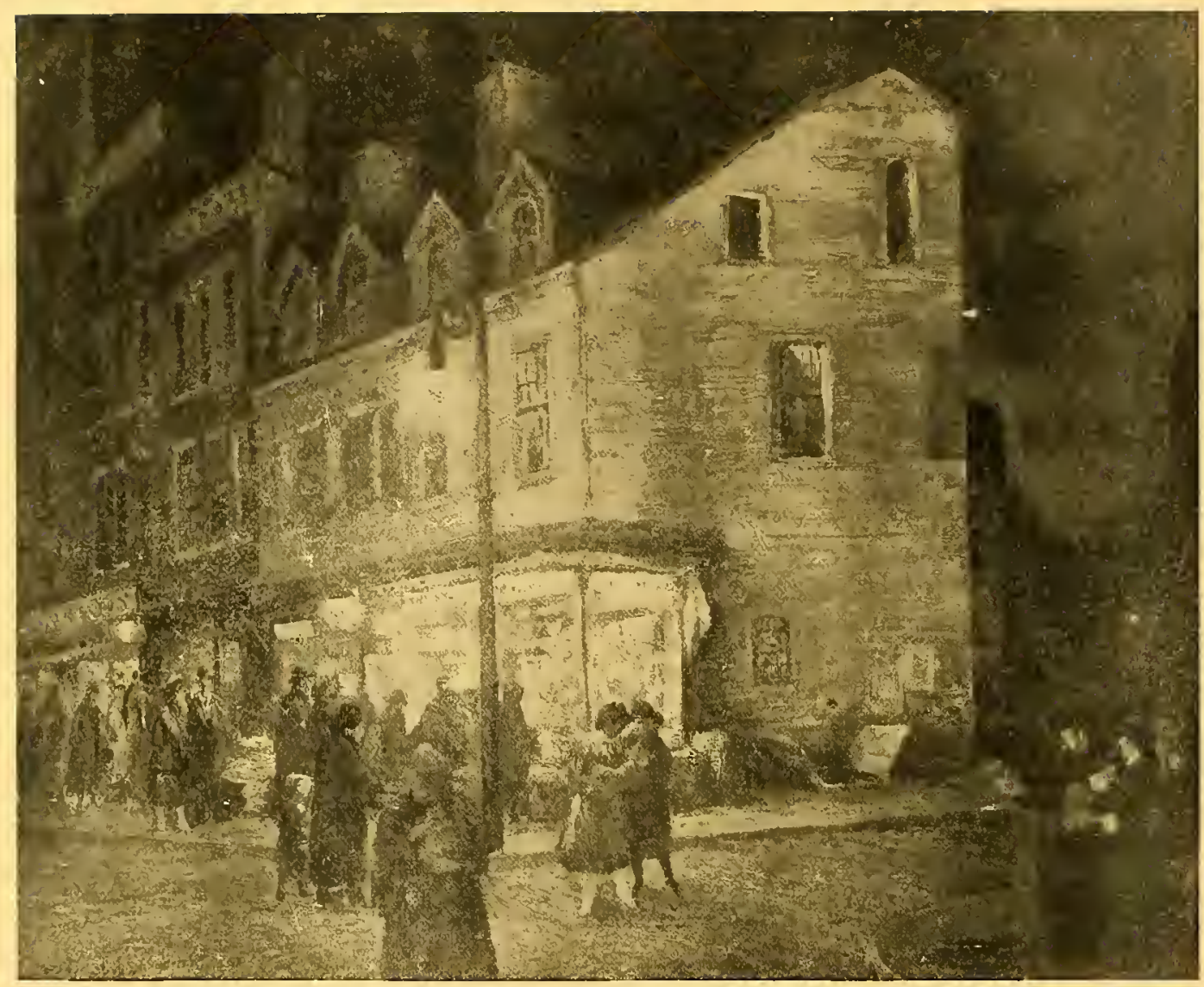

Bleecker Strect Saturday Night by John Sloan 


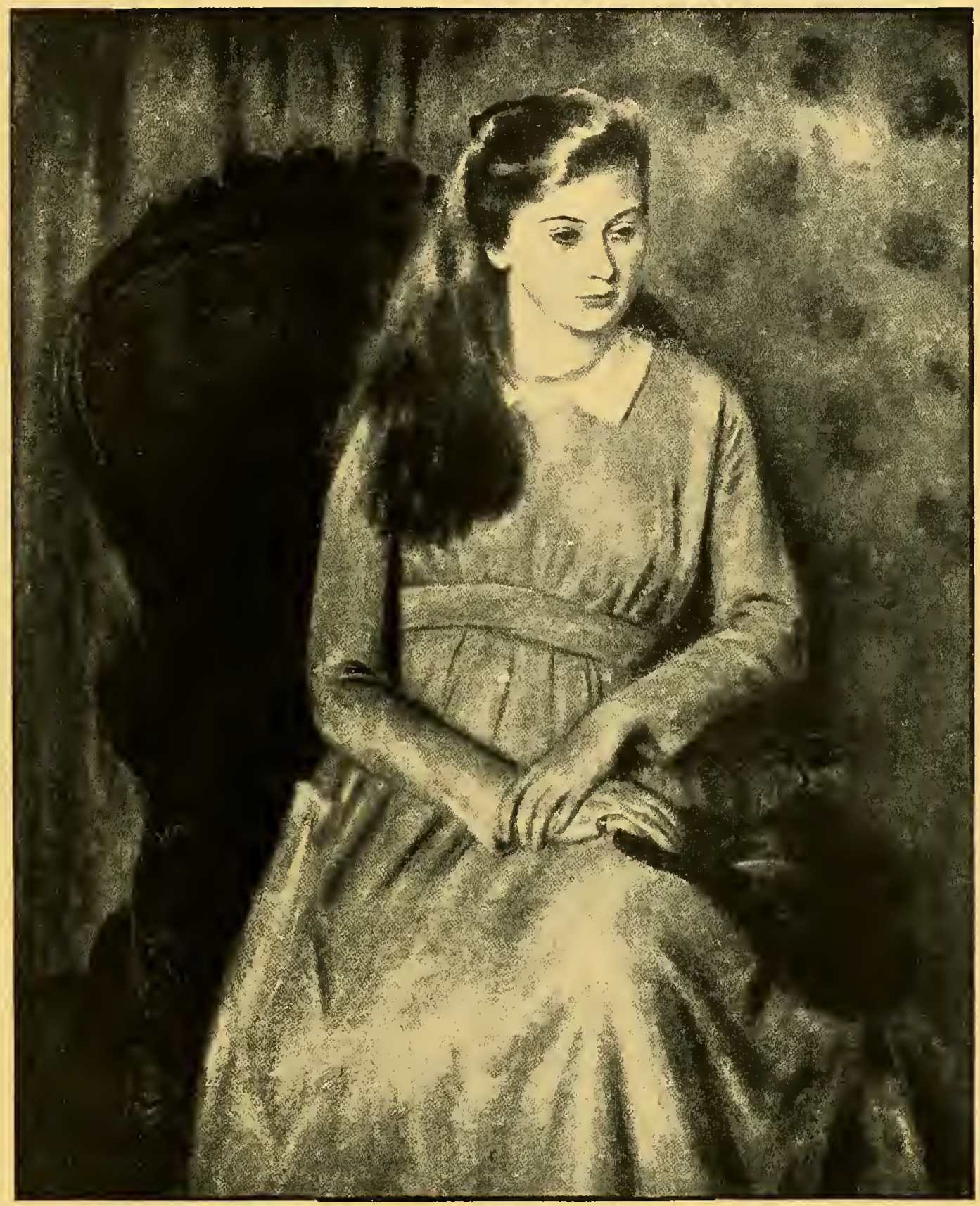

Portrait of Katherine by Eugene Speicher 


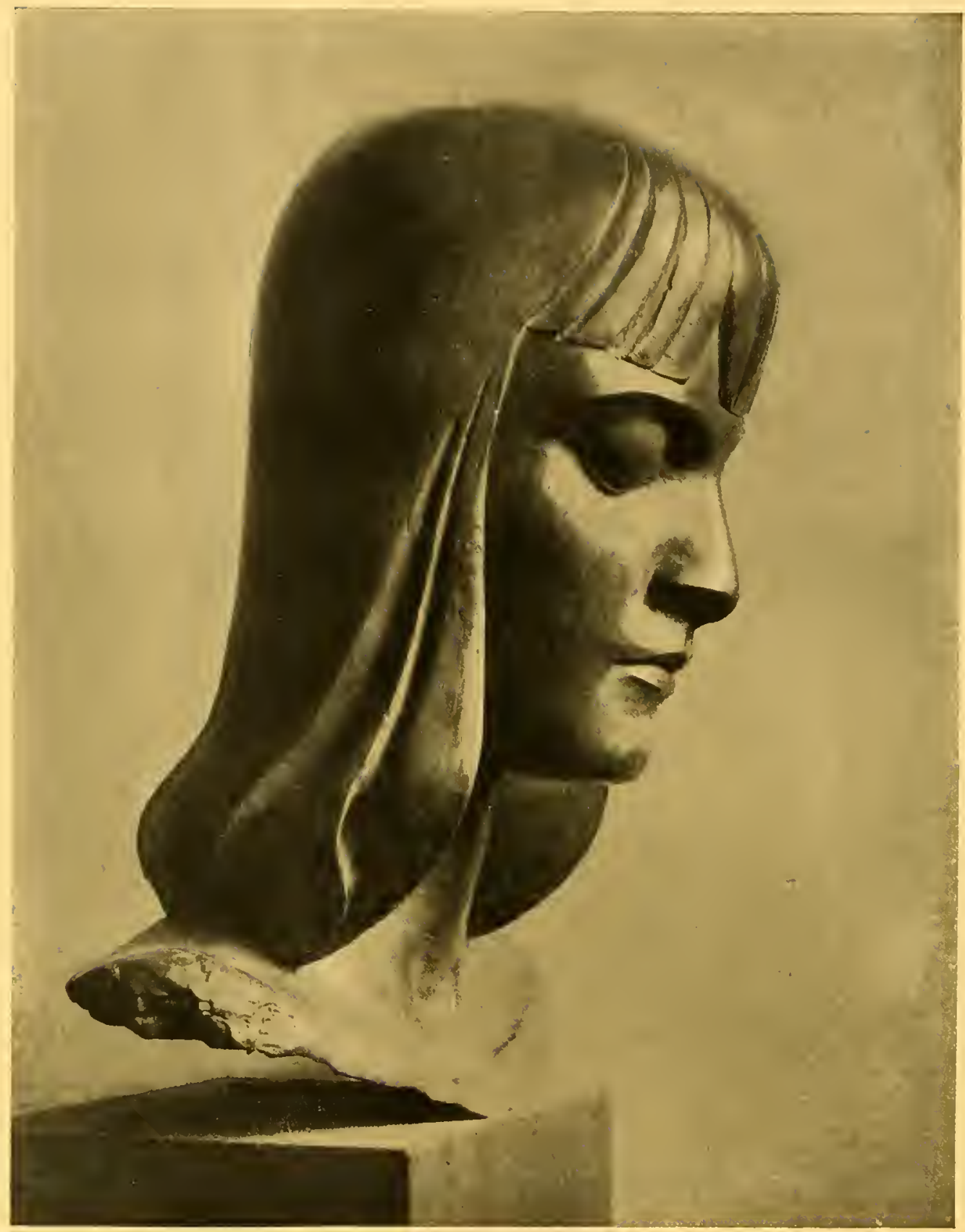

"Senta" by Maurice Sterne 


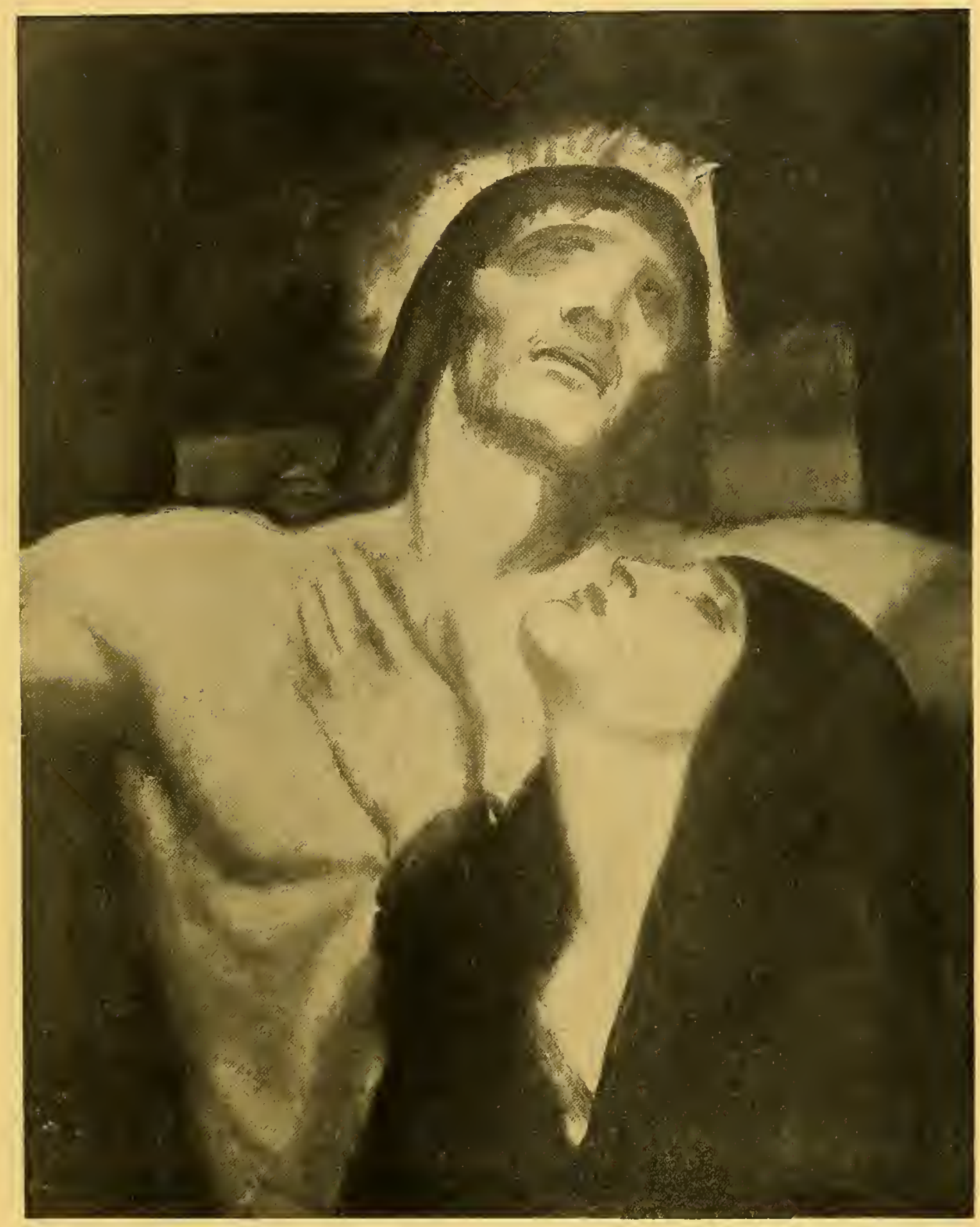

The Passion by Albert Sterner 


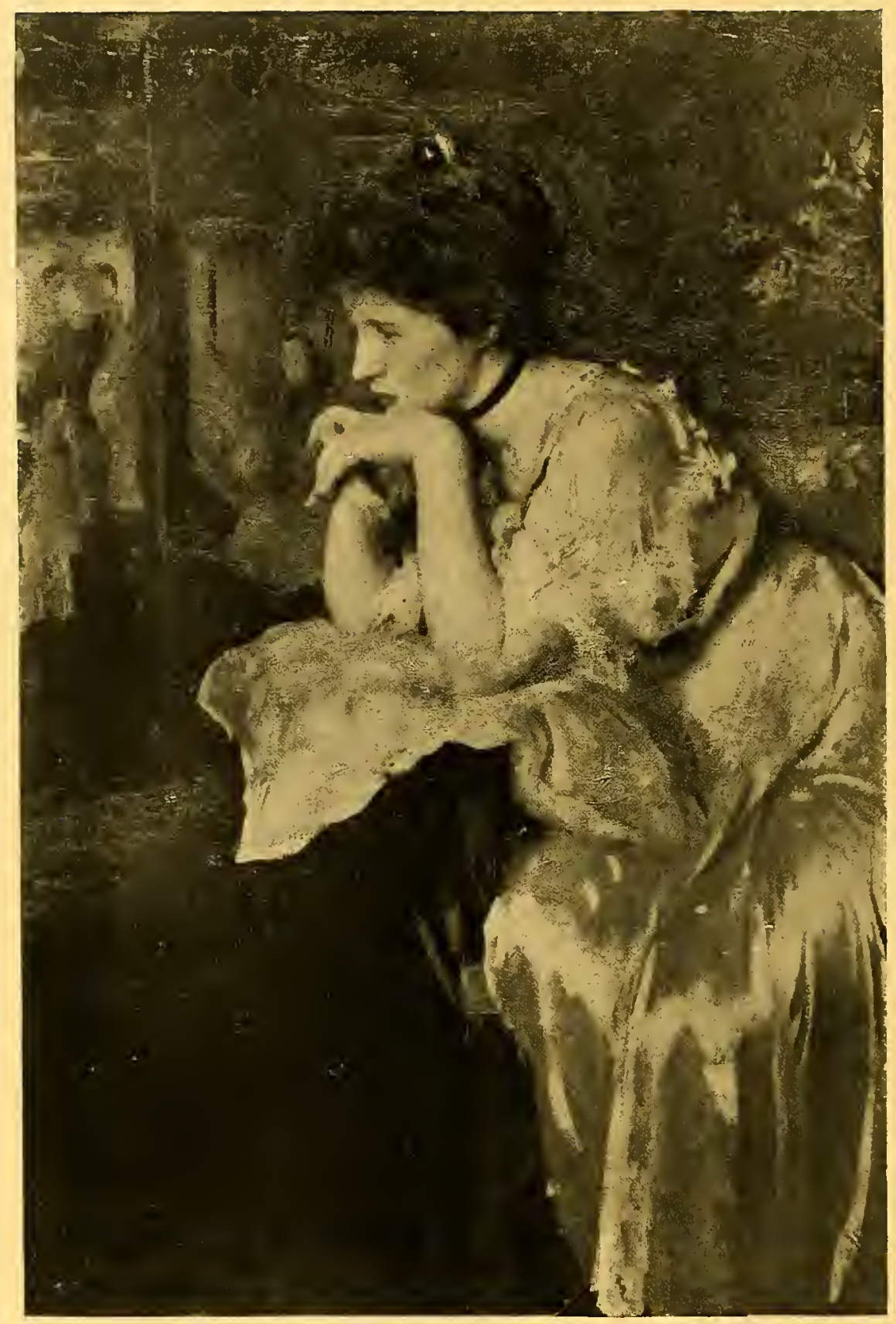

Portrait by Edmund C. Tarbell 


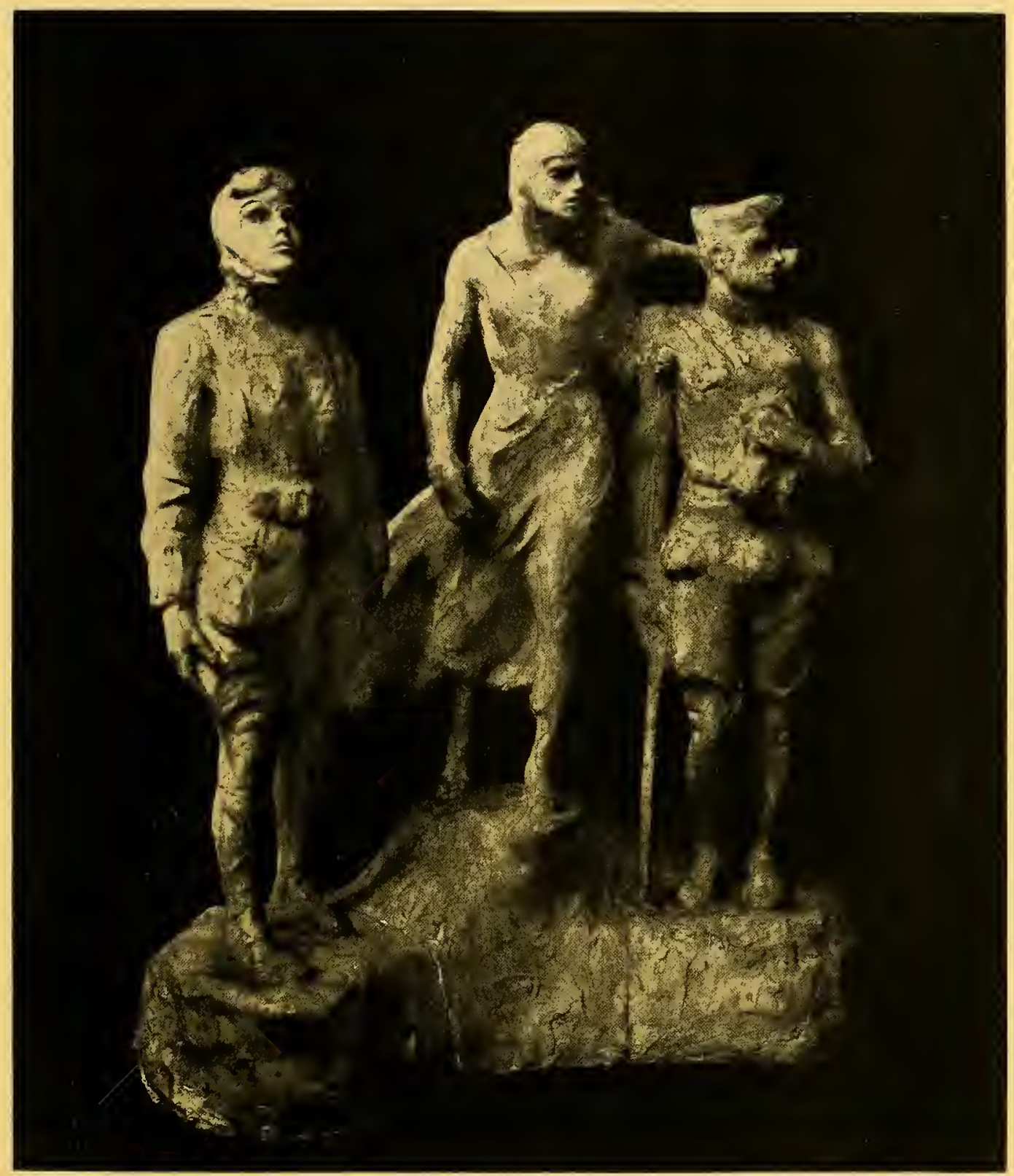

Spirit of the Red Cross by Gertrude V. Whitney 


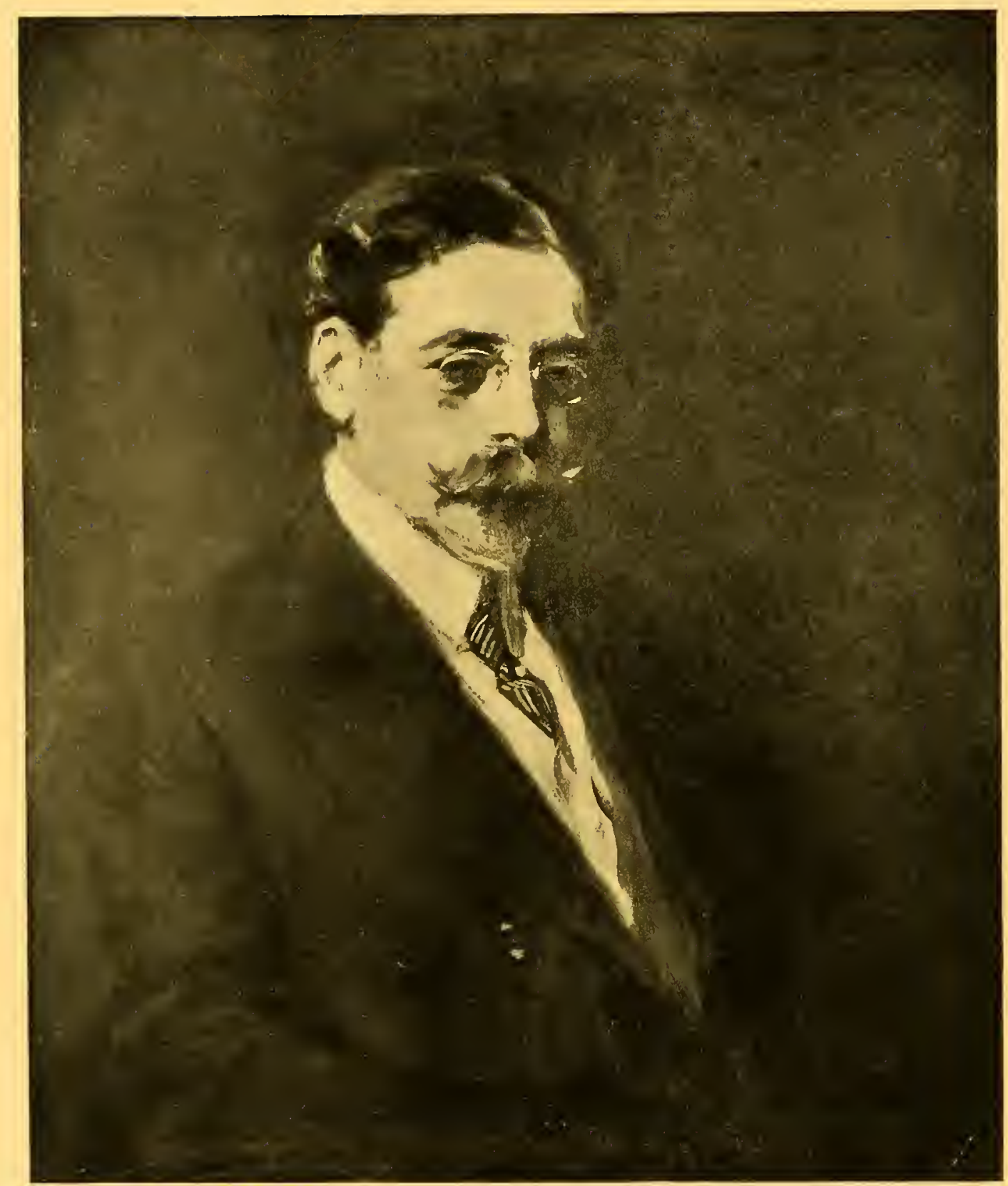

Arnold Brunner, Esq., by Irving R. Wiles 


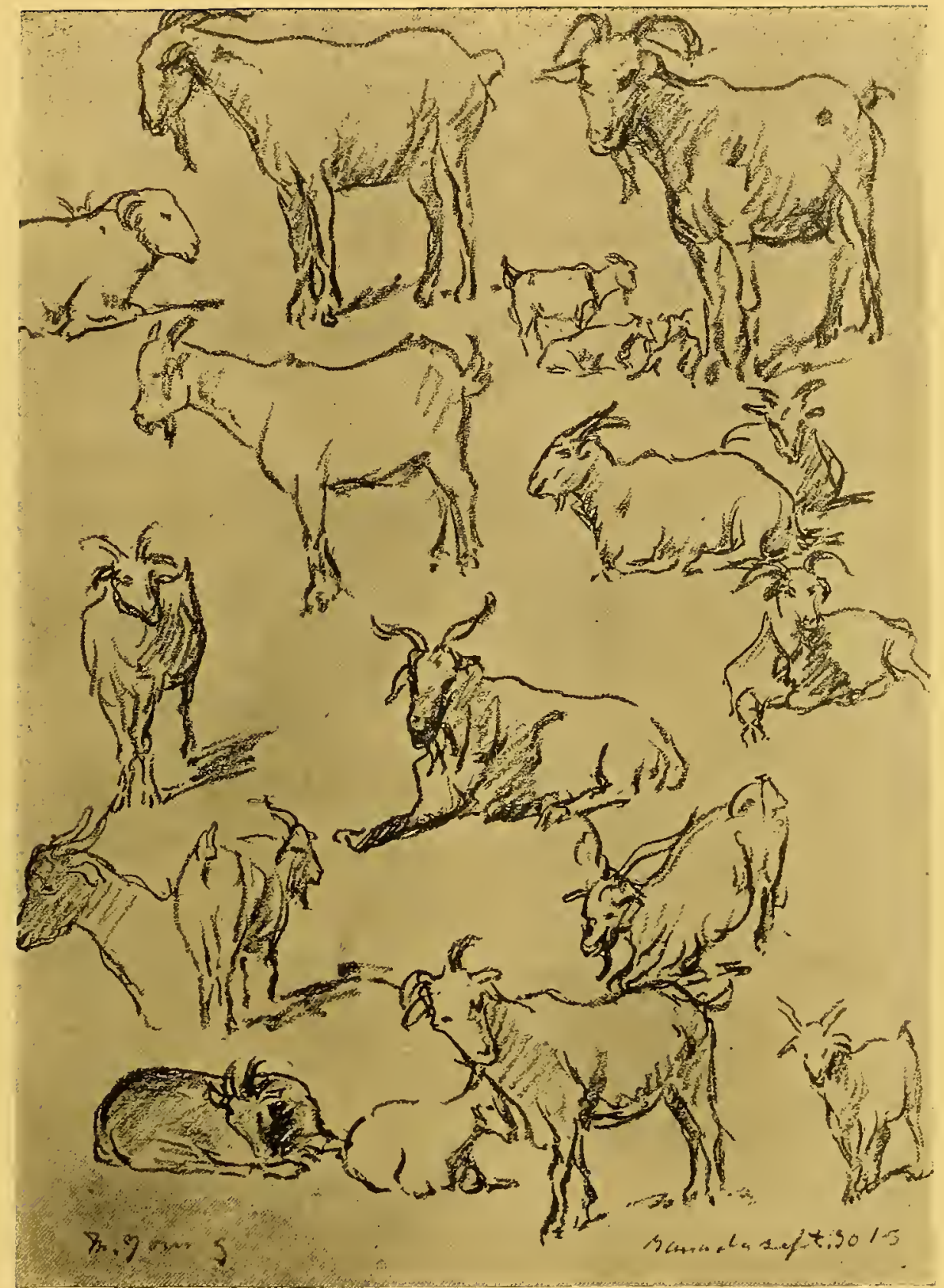

Study of Navajo Goats by Mahonri Young 


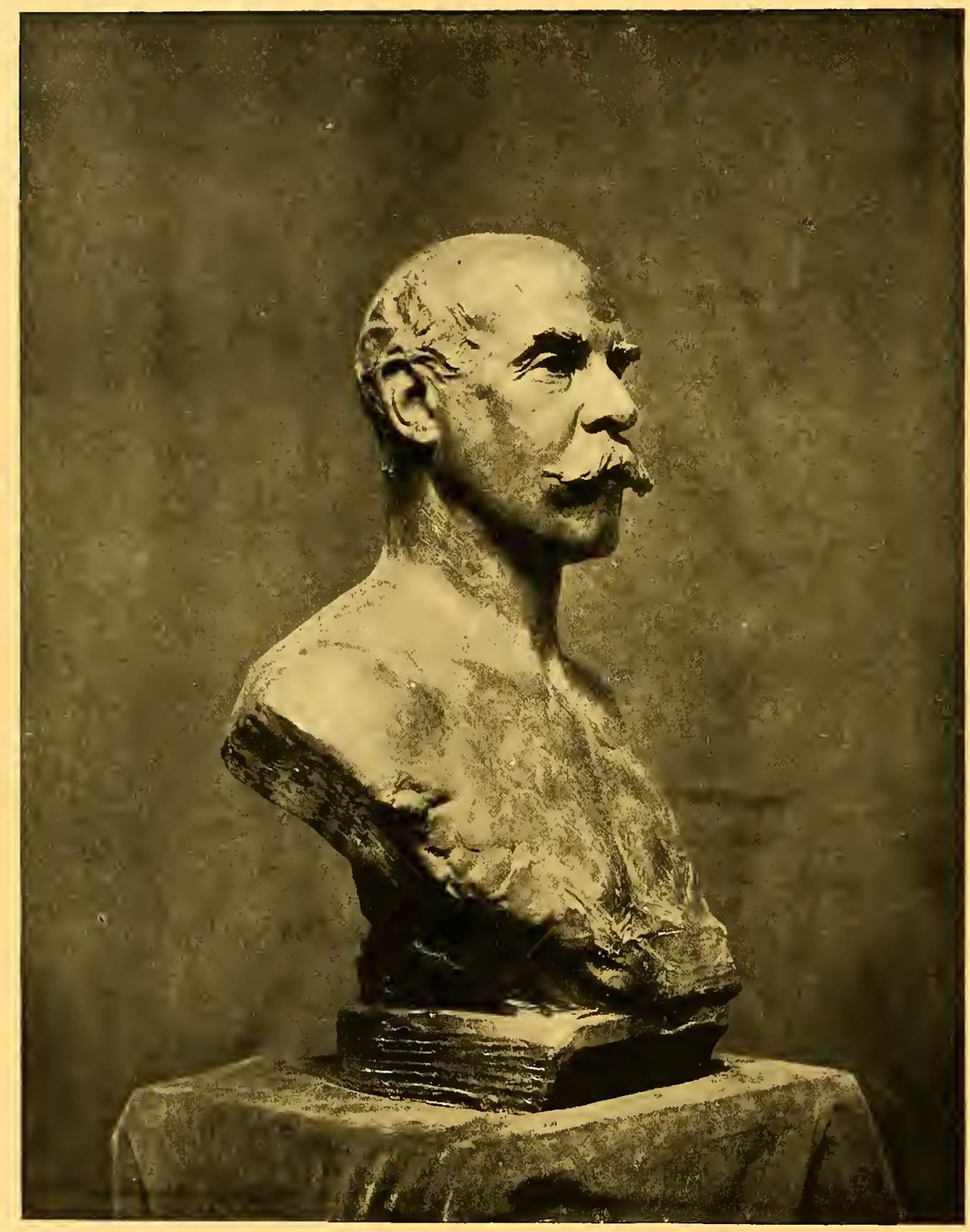

Portrait of Madison Grant by Chester Beach 


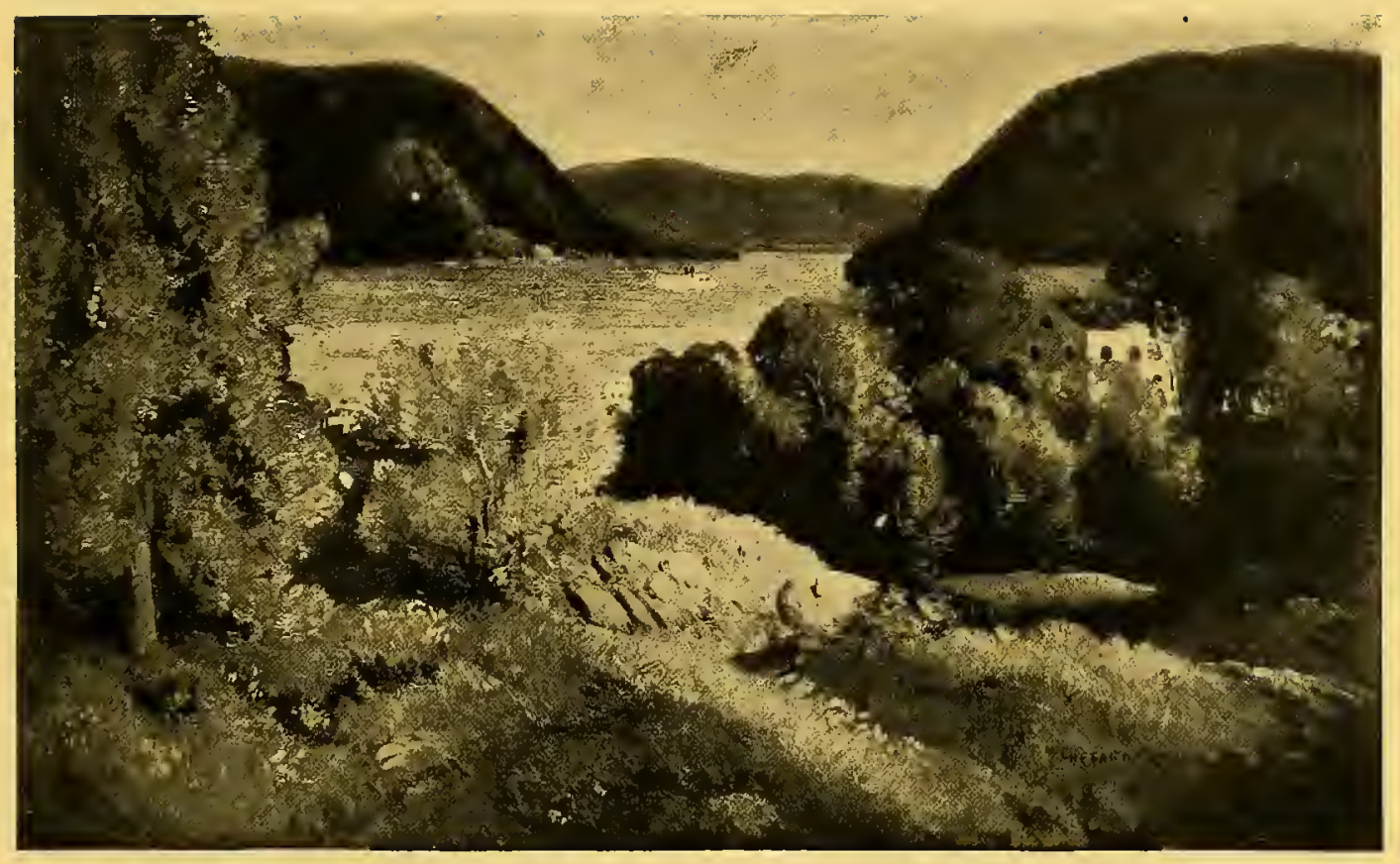

The Gate of the Highlands by Gifford Beal 


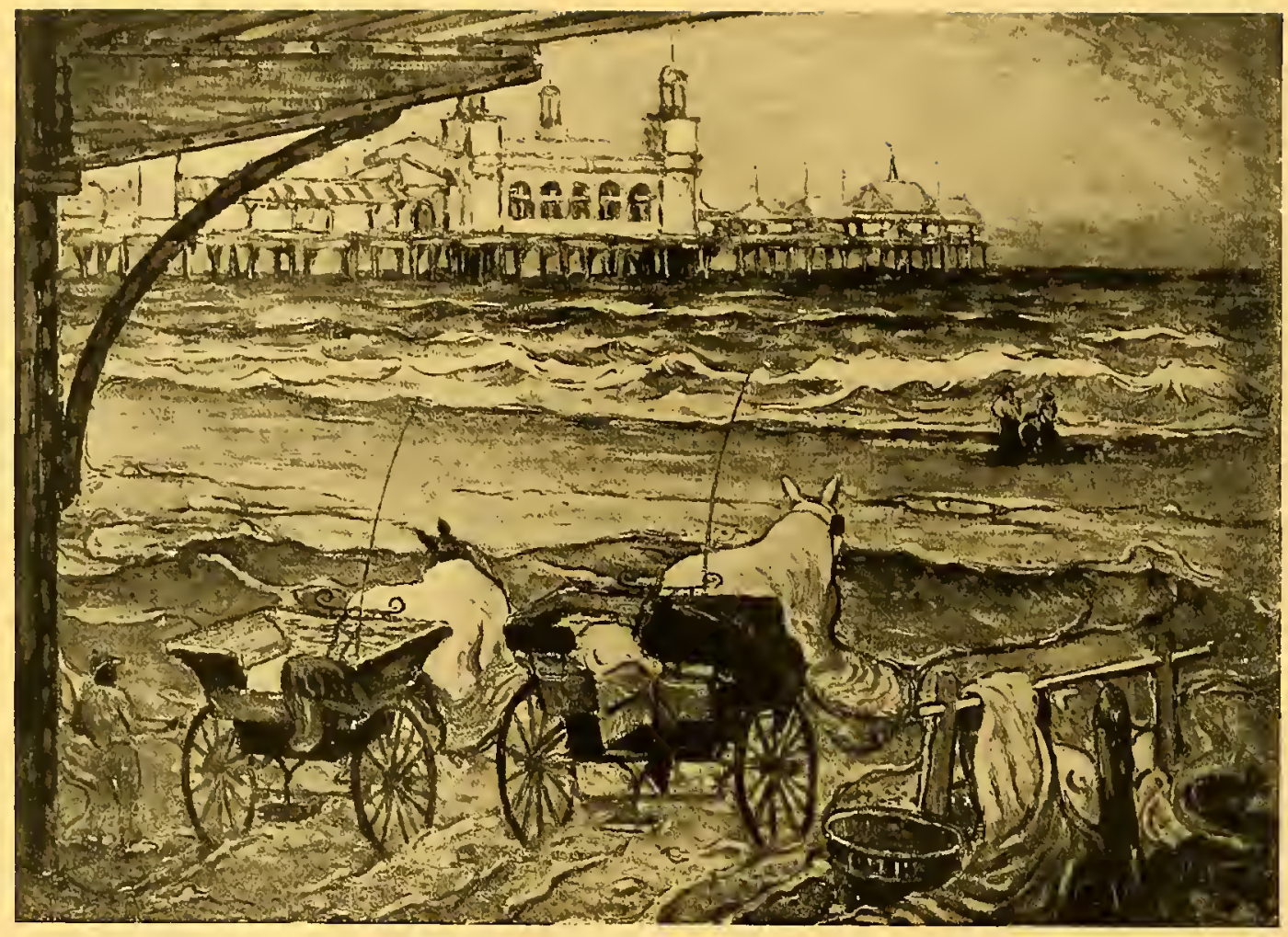

The Beach Ponies by Reynolds Beal 


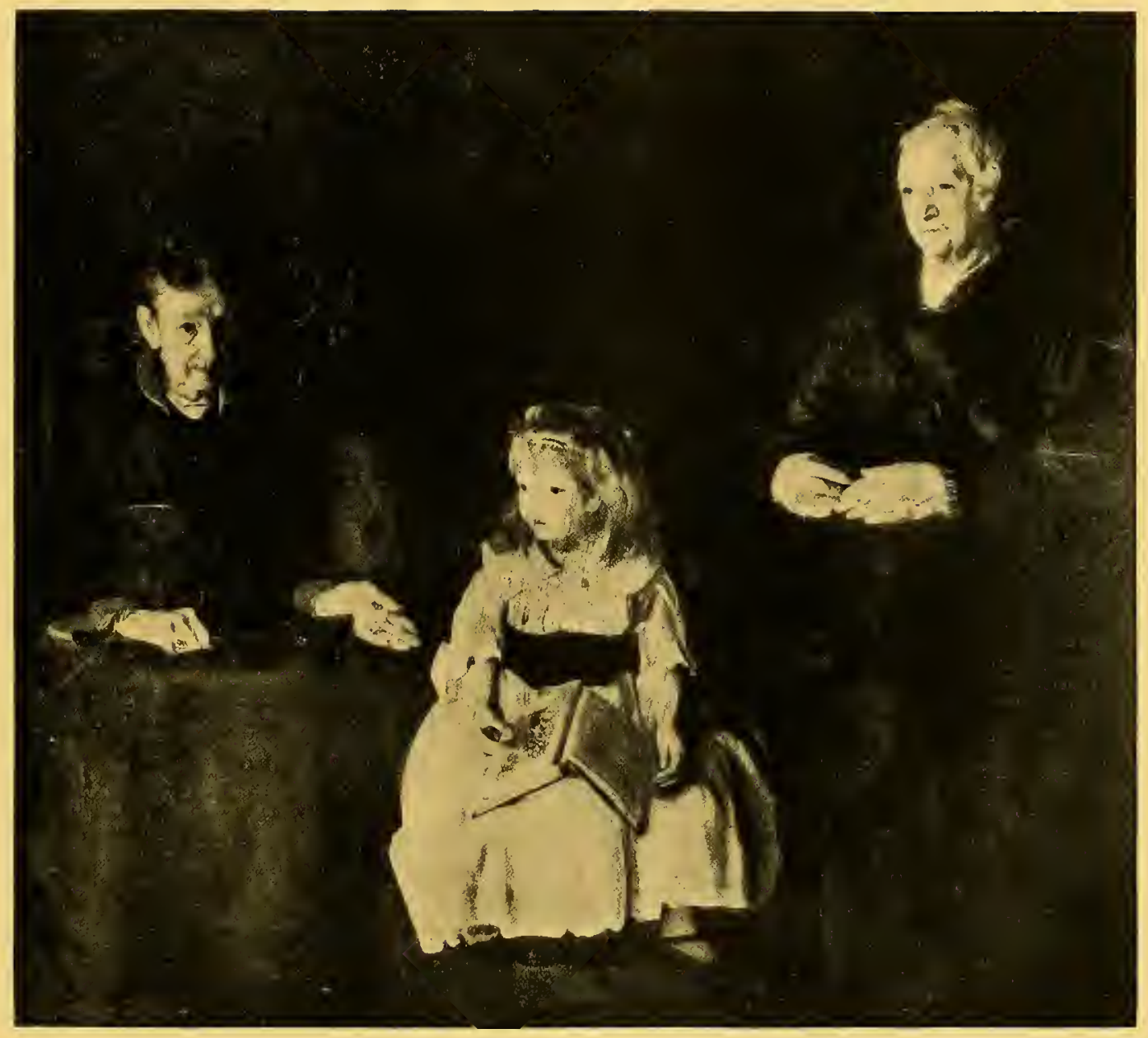

Eleanor, Jean and Anna by George Bellows 


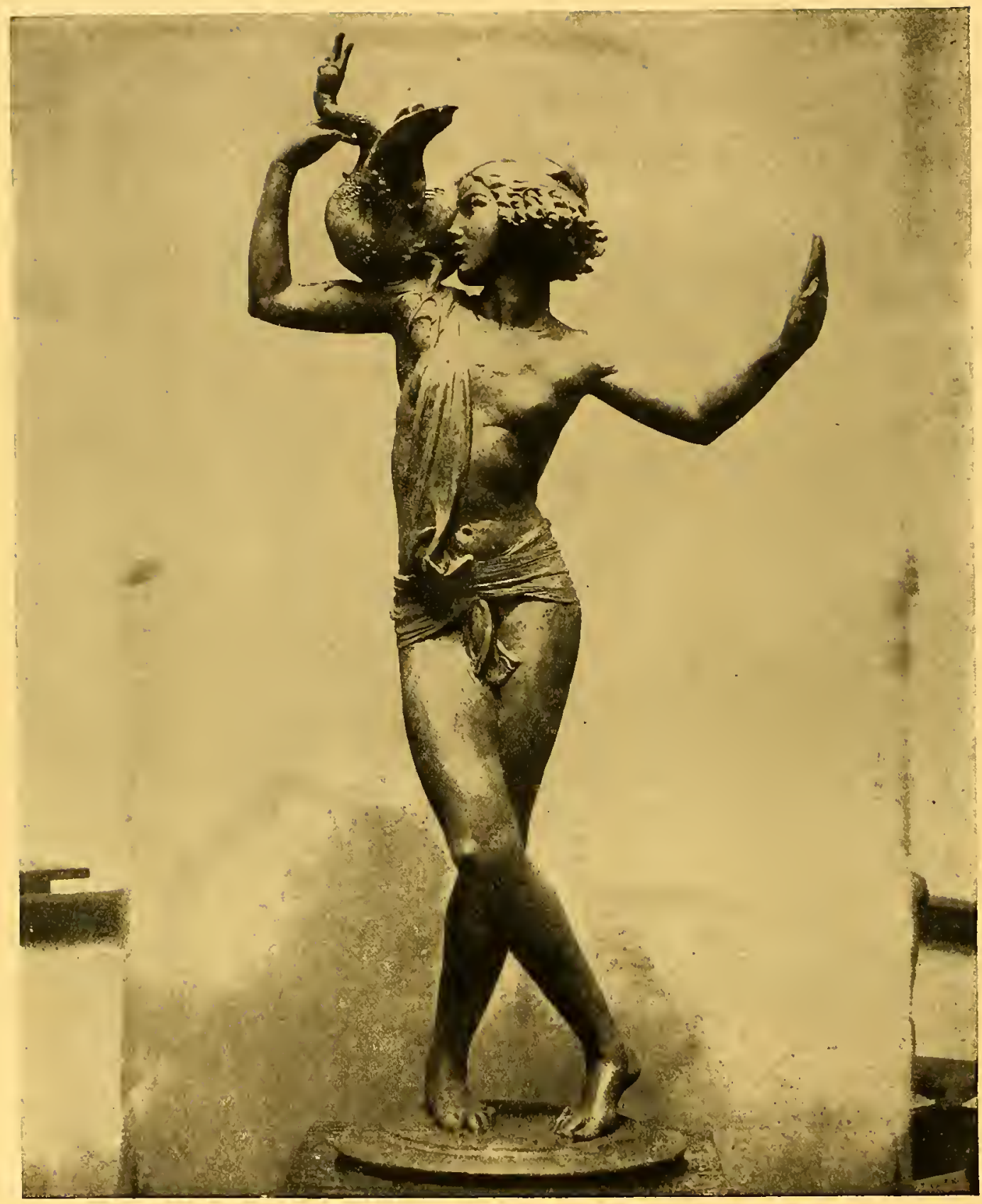

"The Little Dear with the Tiny Black Swan" by A. Stirling Calder 


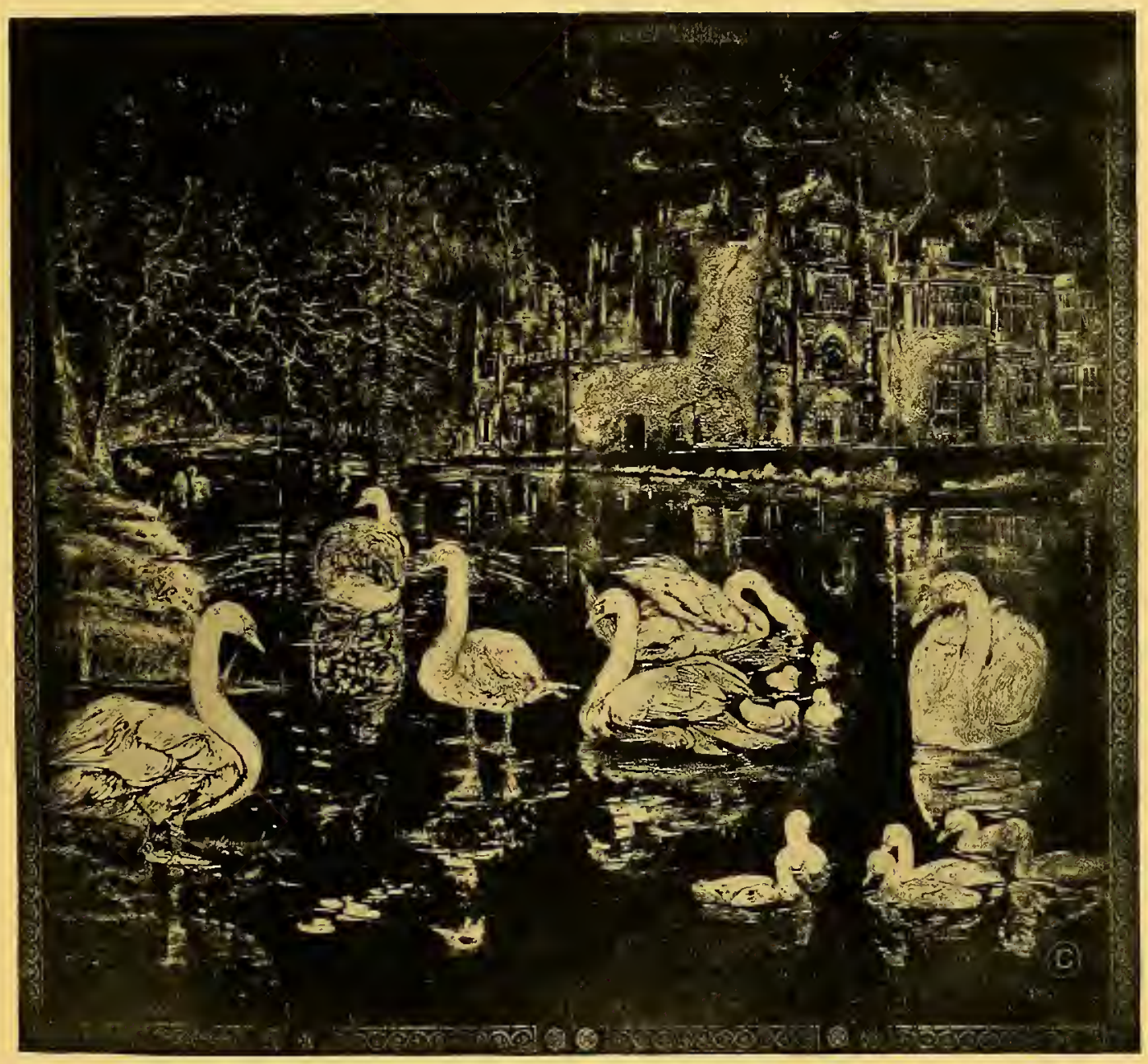

Swan Screen by Robert W. Chanler 


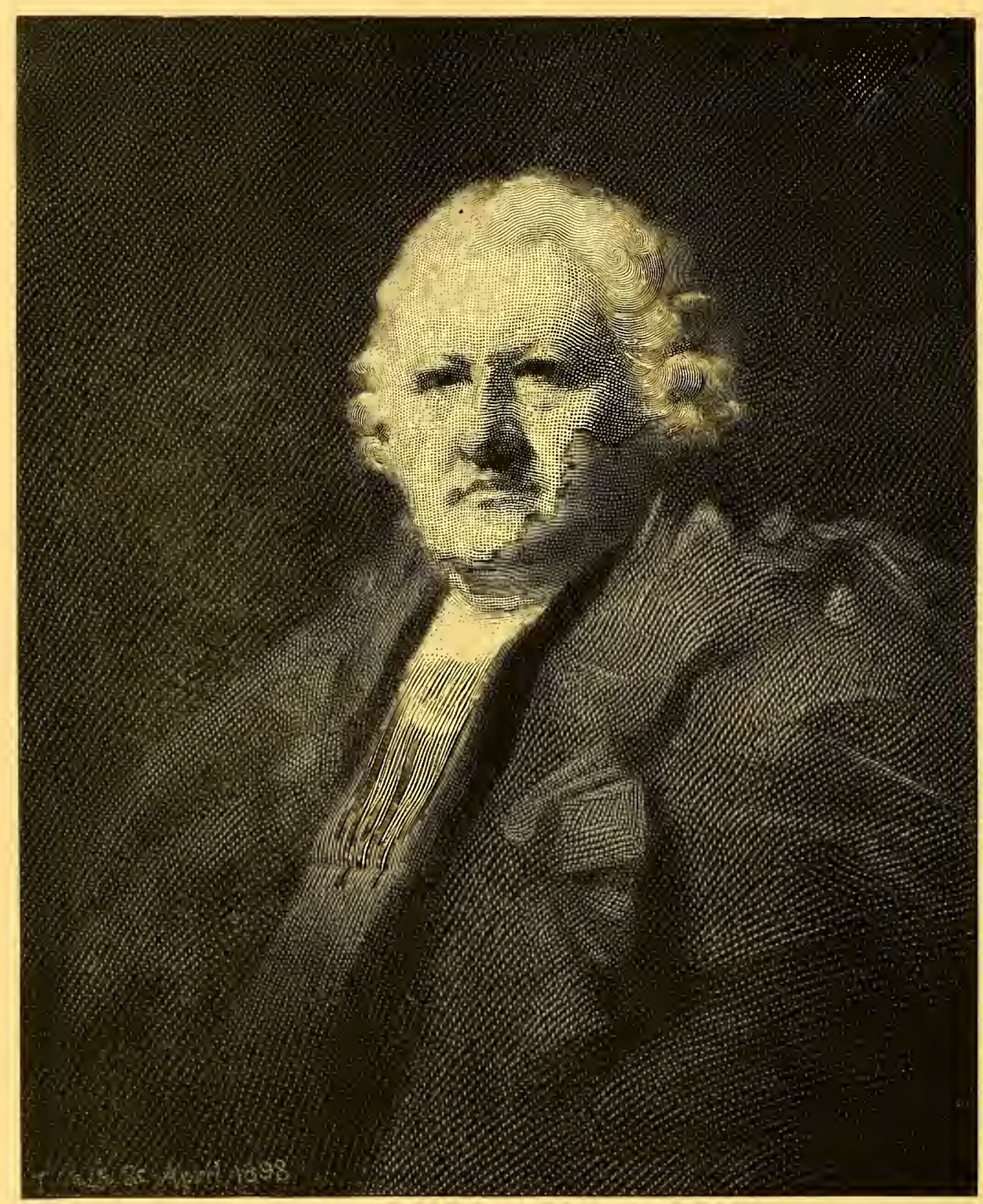

Portrait by Timothy Cole 


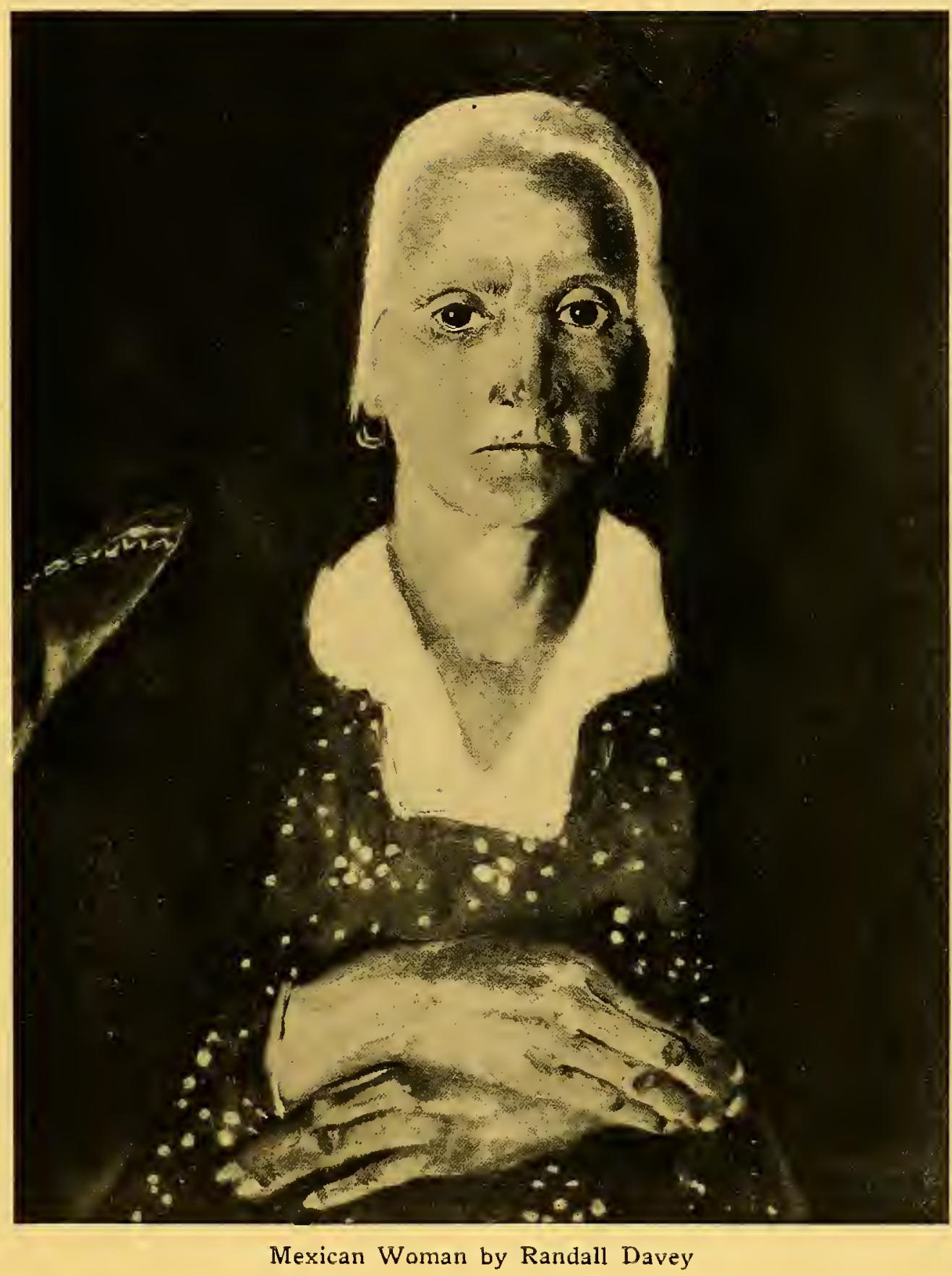




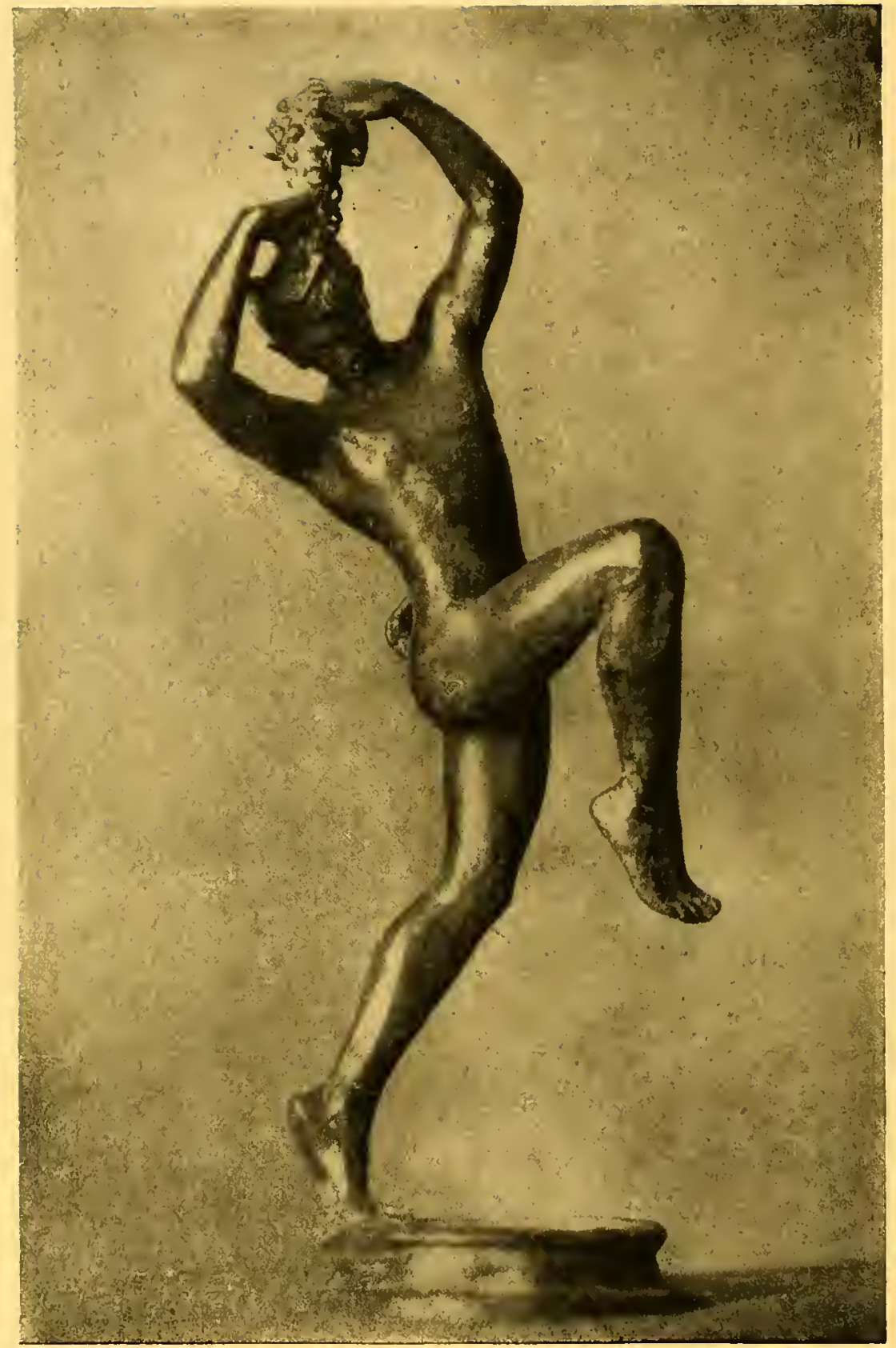

Dancing Figure by Hunt Diederich 


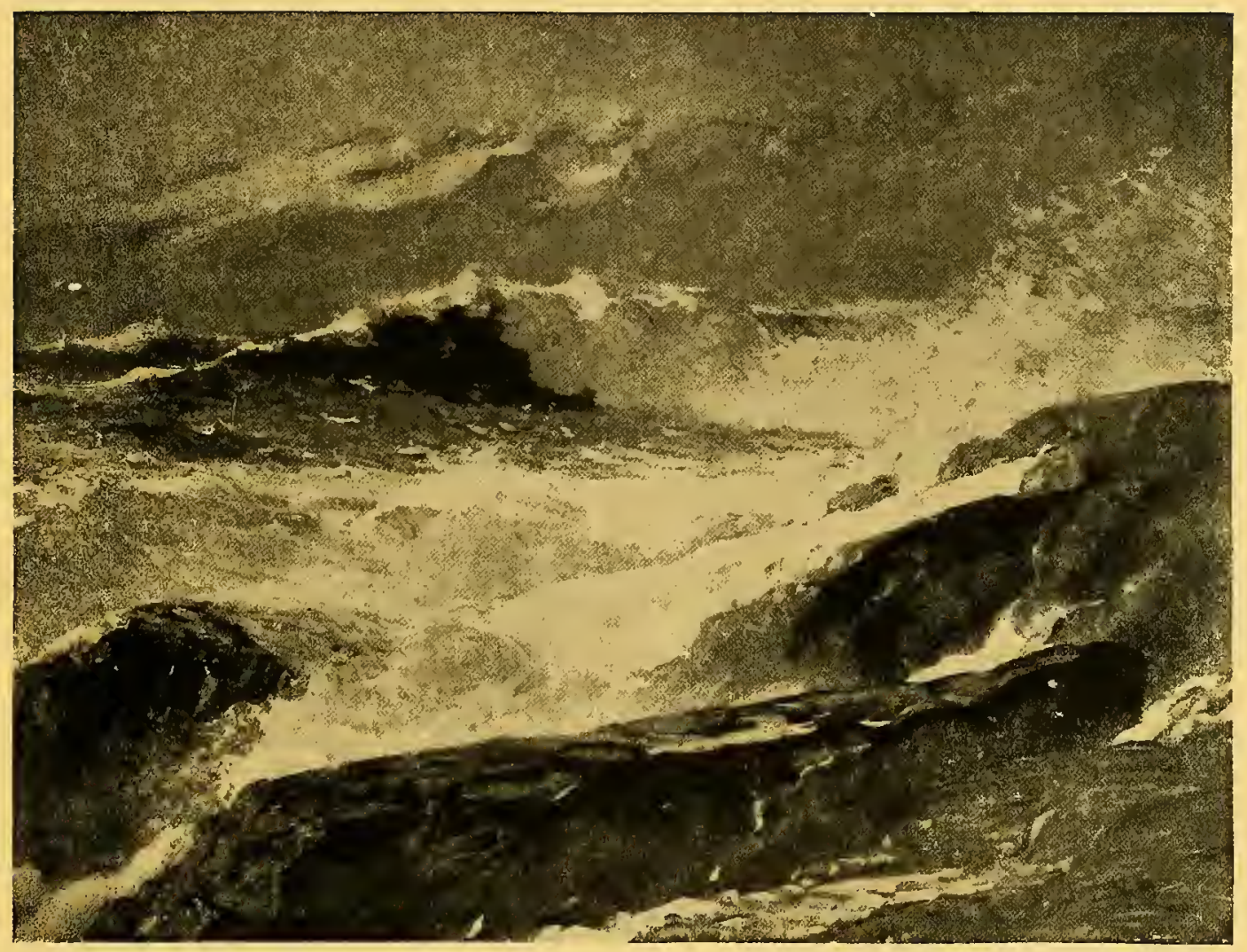

Clearing after Gale by Paul Dougherty 


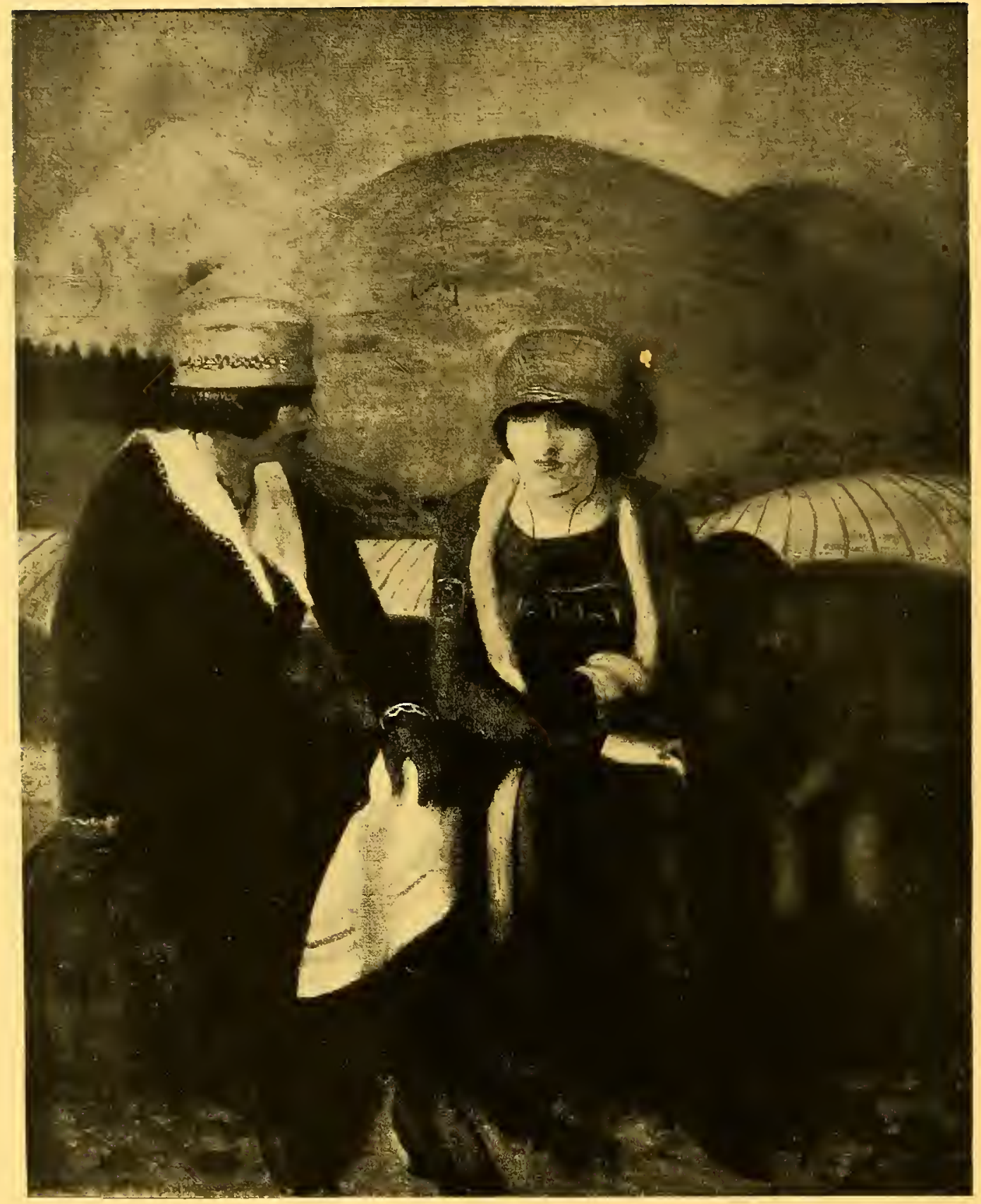

Figures by Guy Pène du Bois 


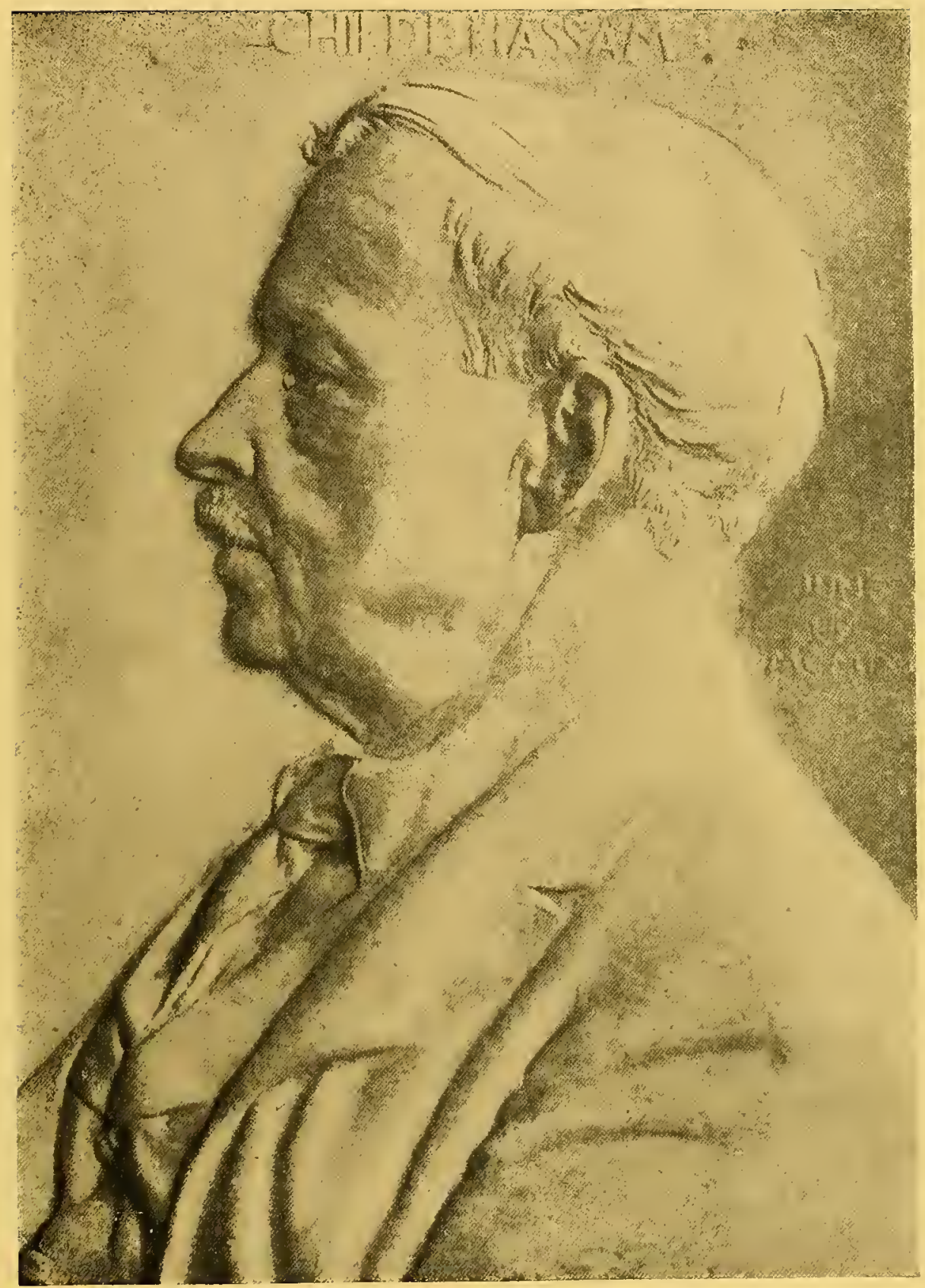

Portrait of Childe Hassam by John Flanagan 


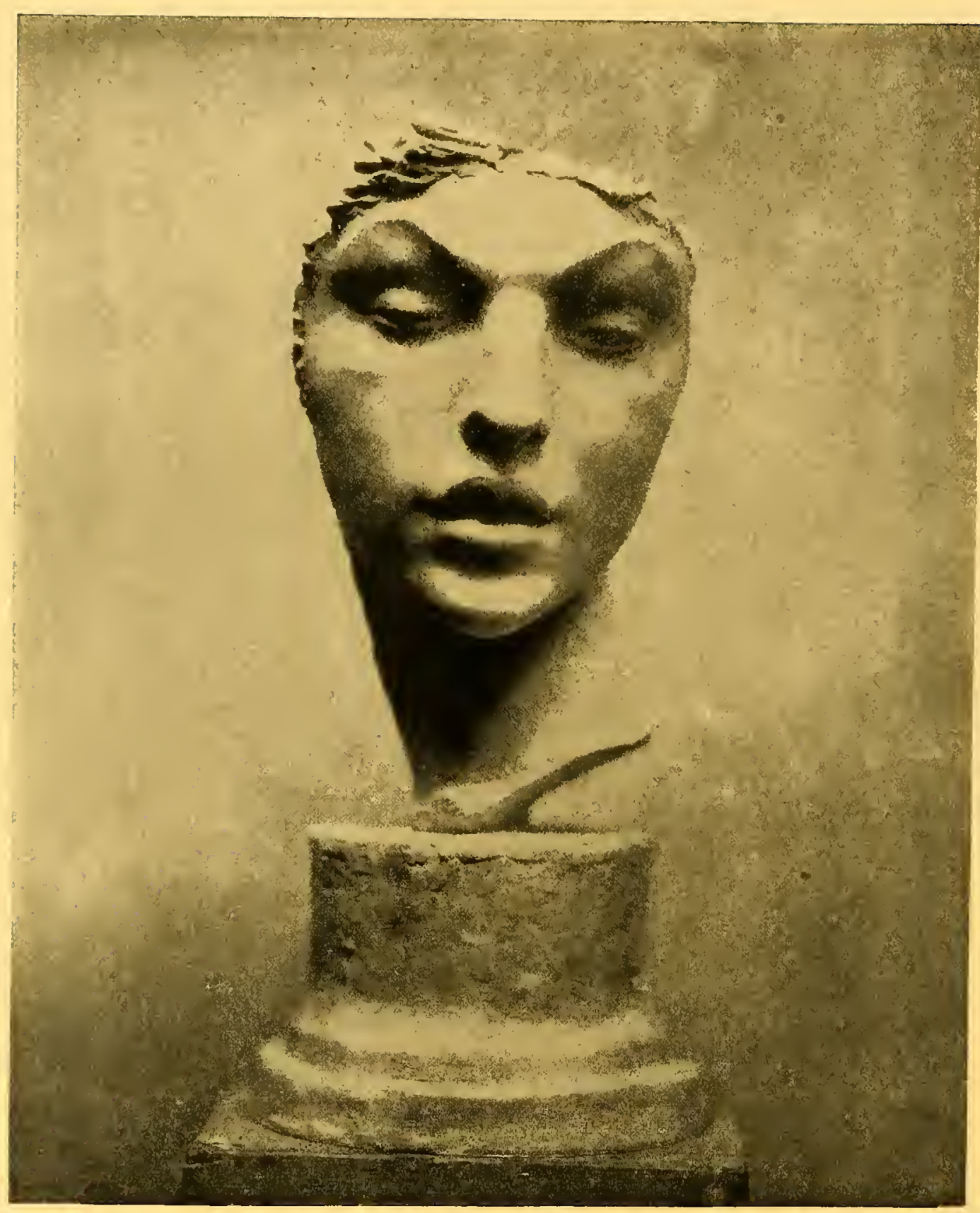

Mask by James Earle Frazer 


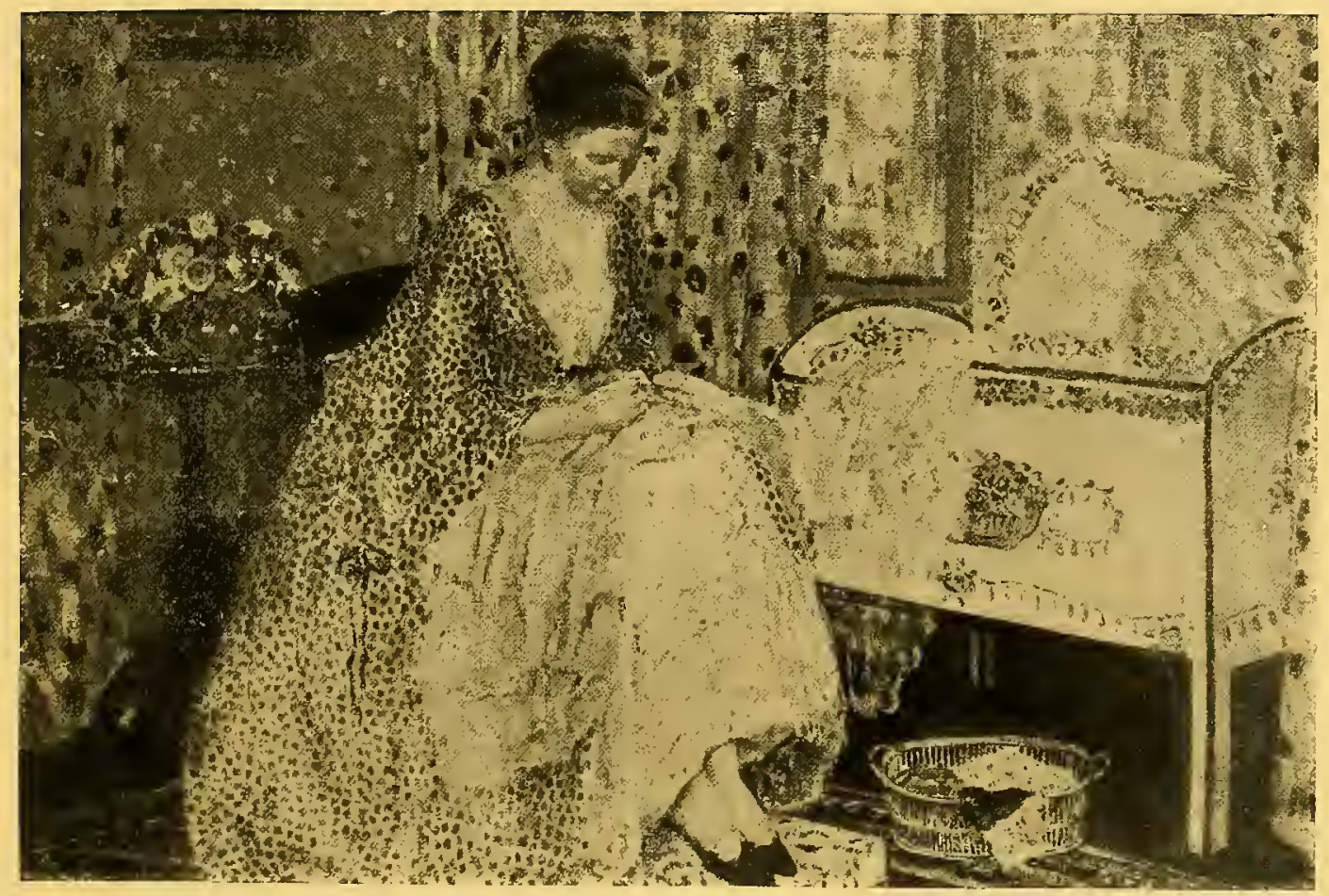

The Mother by Frederick E. Frieseke 


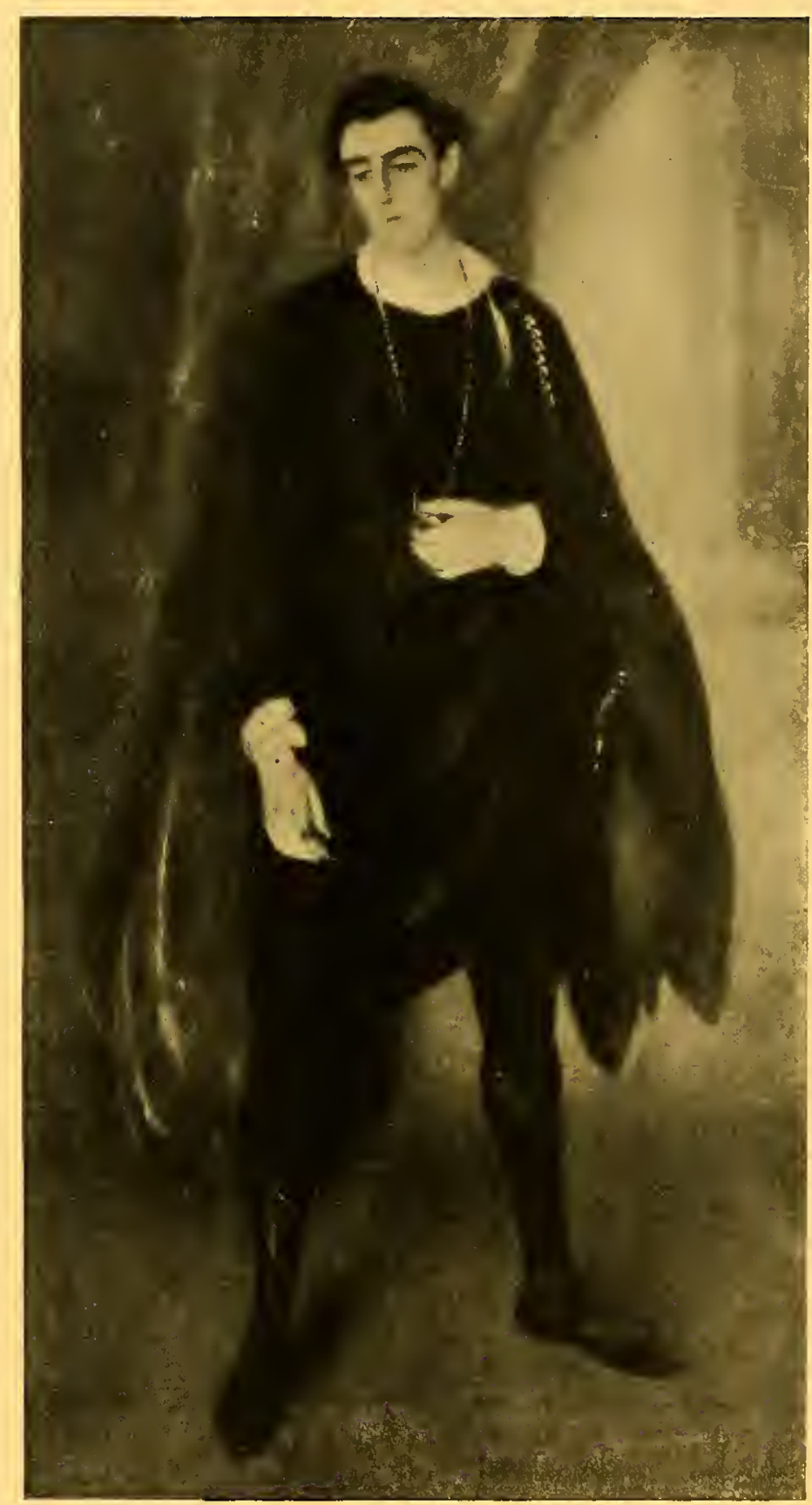

William Hampden as Hamlet by William J. Glackens 


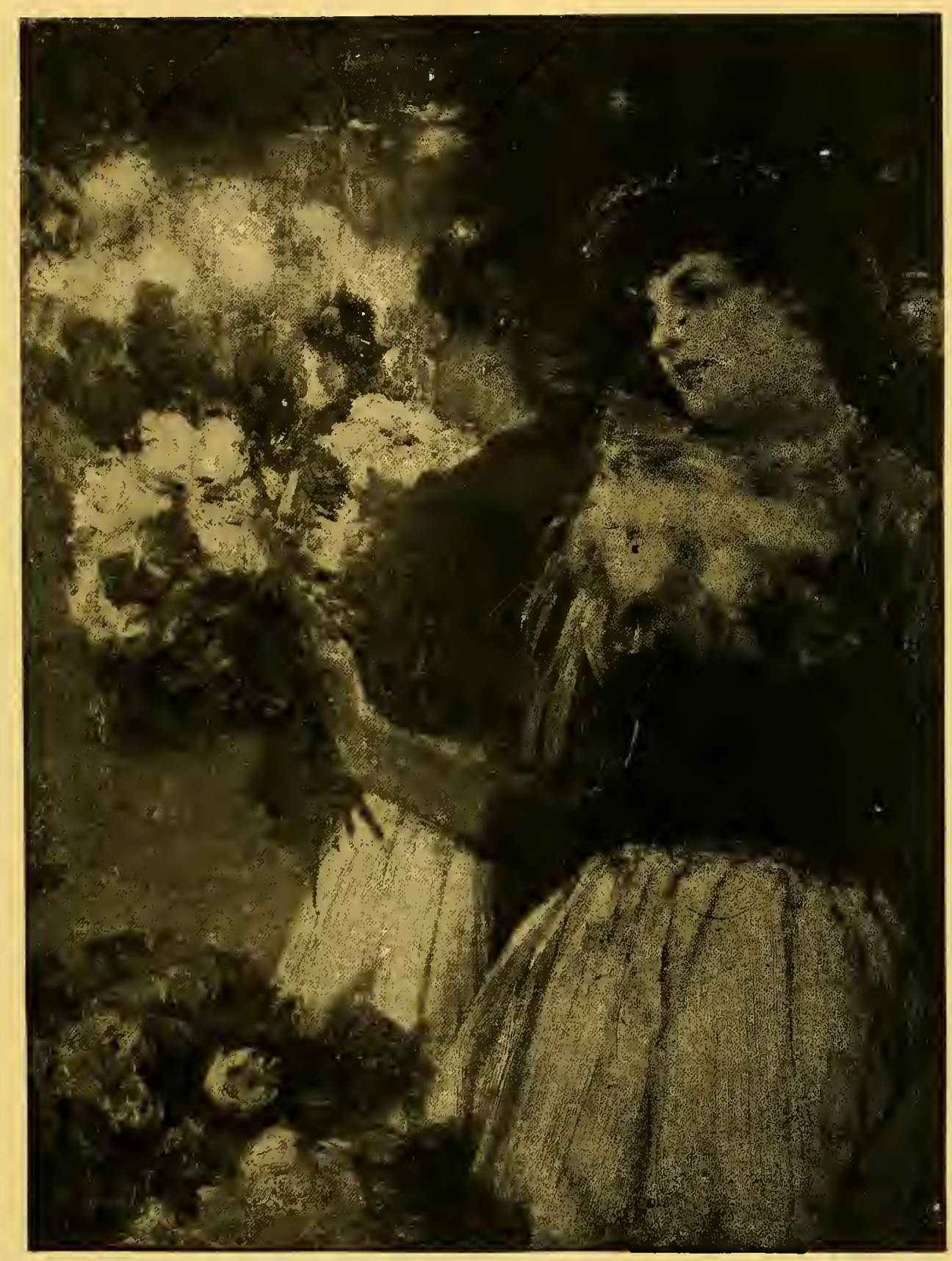

Peony Girl by Childe Hassam 


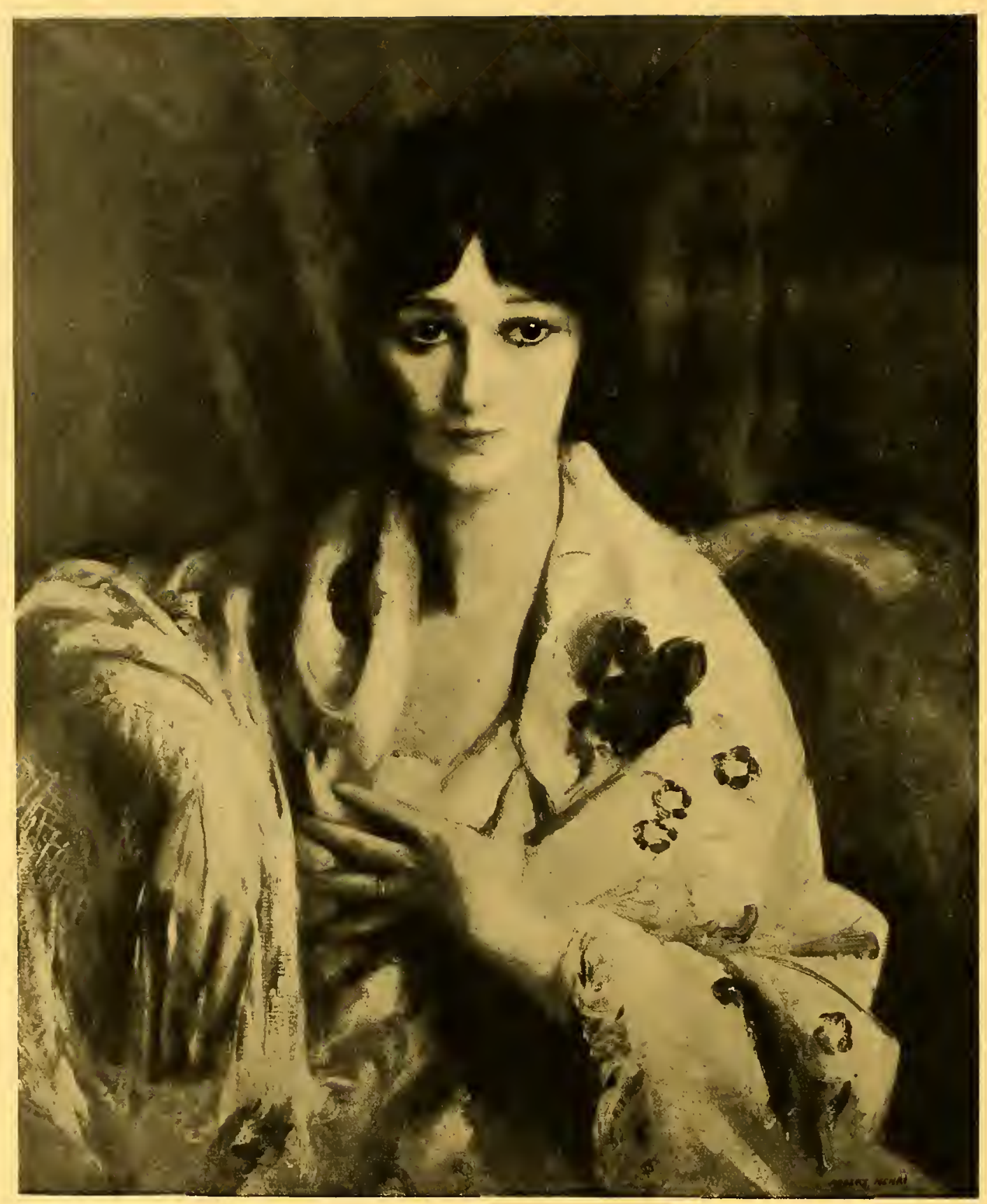

Christine by Robert Henri 


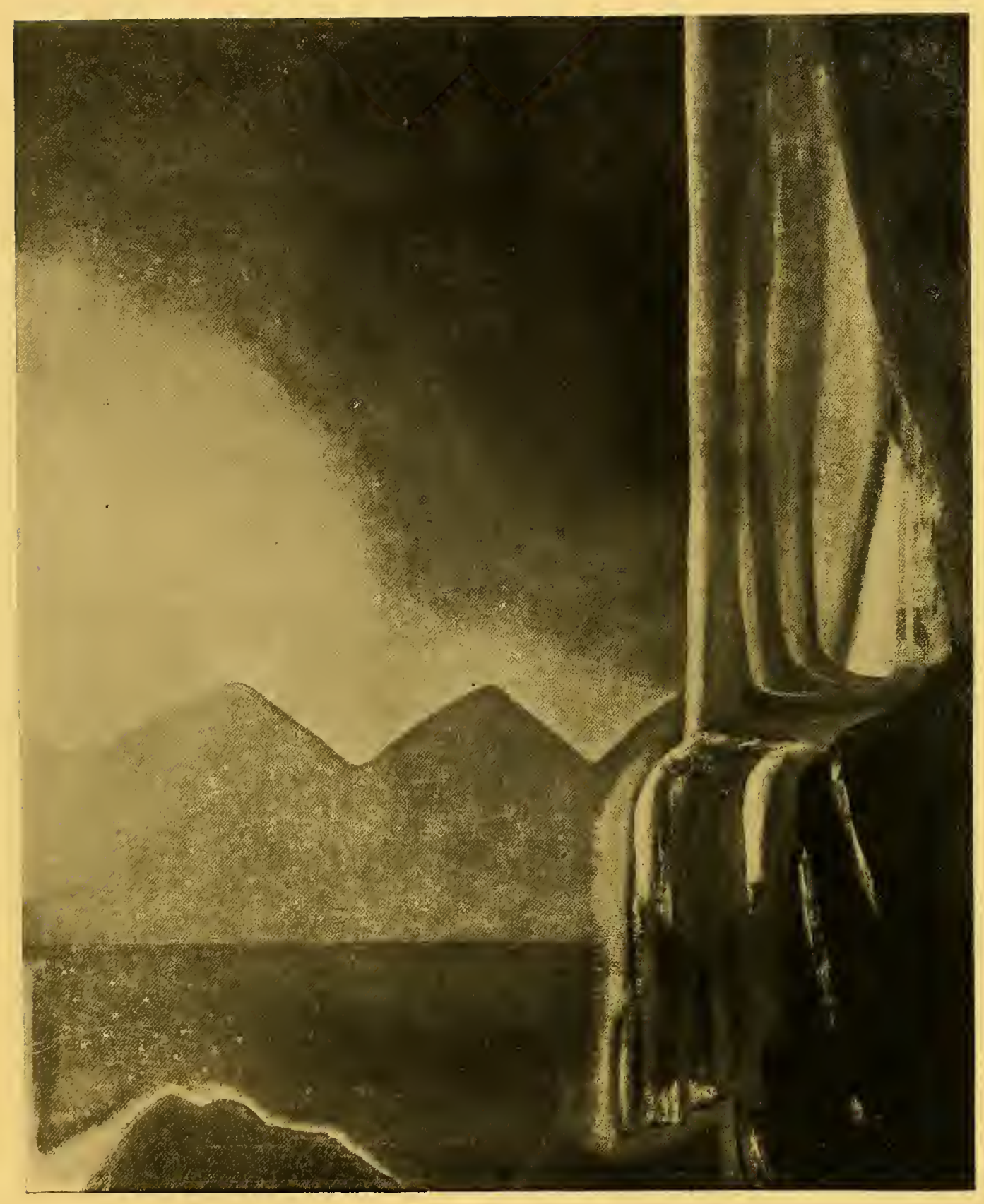

Sun and Sea by Rockwell Kent 


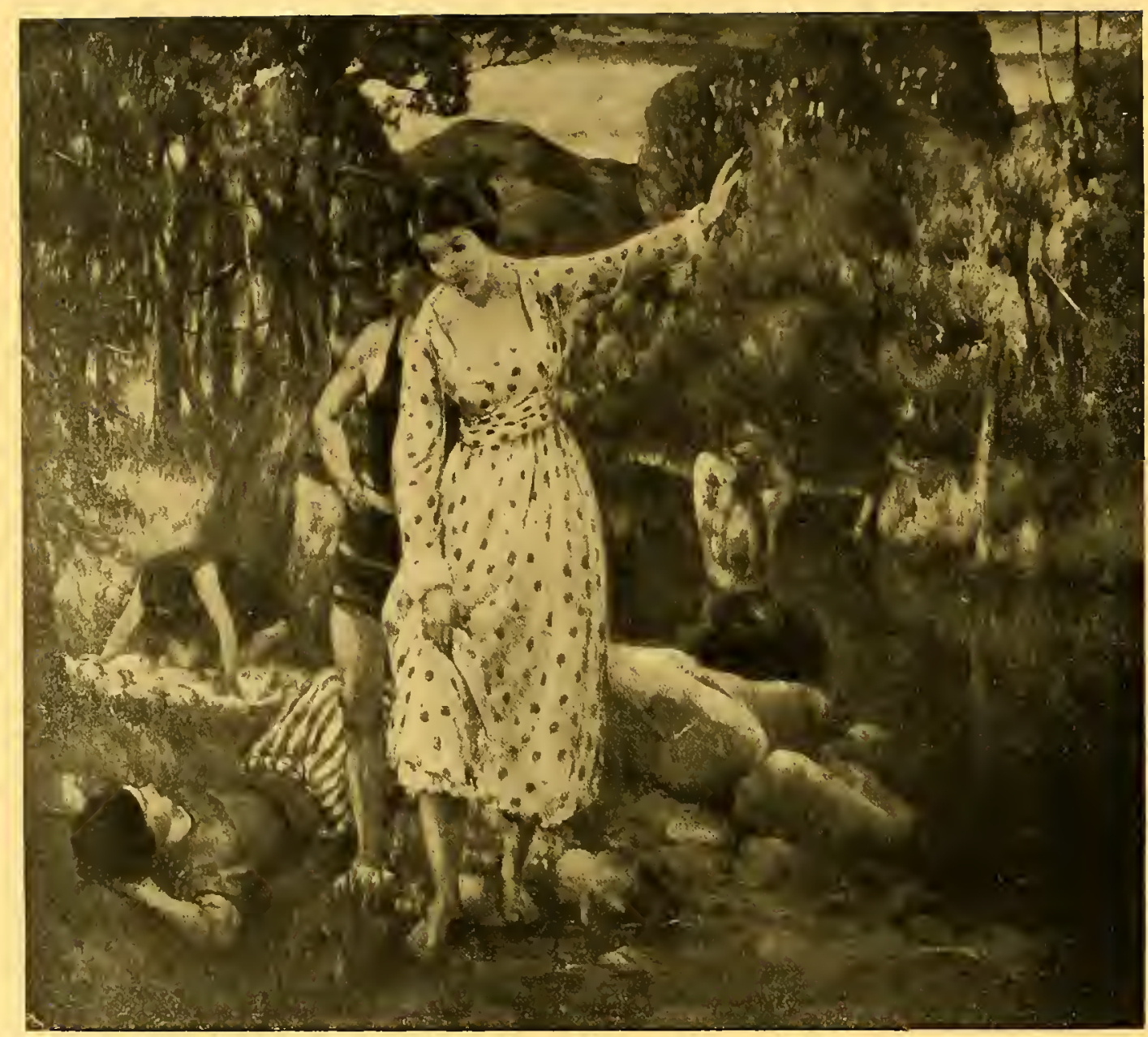

A Day in August by Leon Kroll 


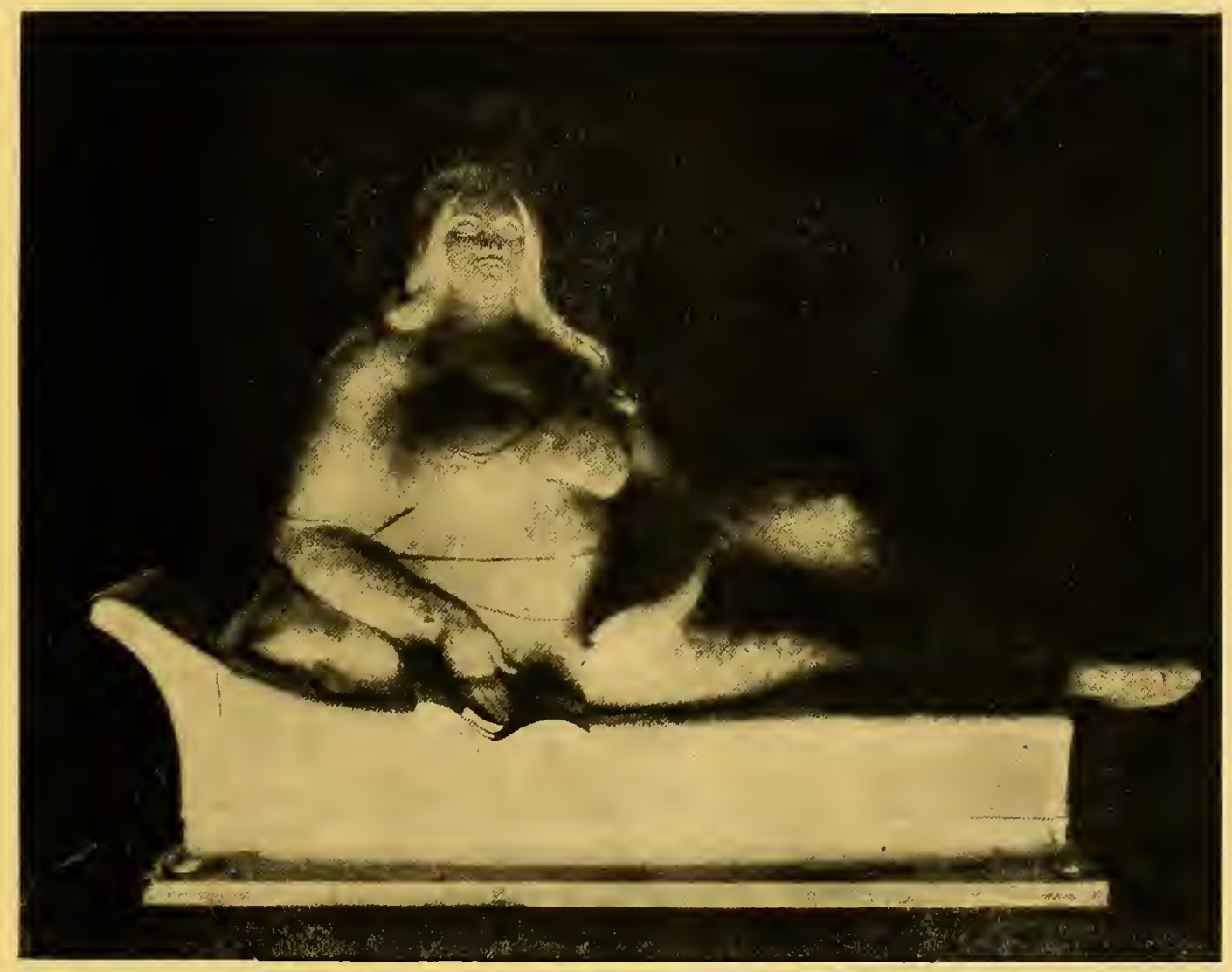

Home by Gaston Lachaise 


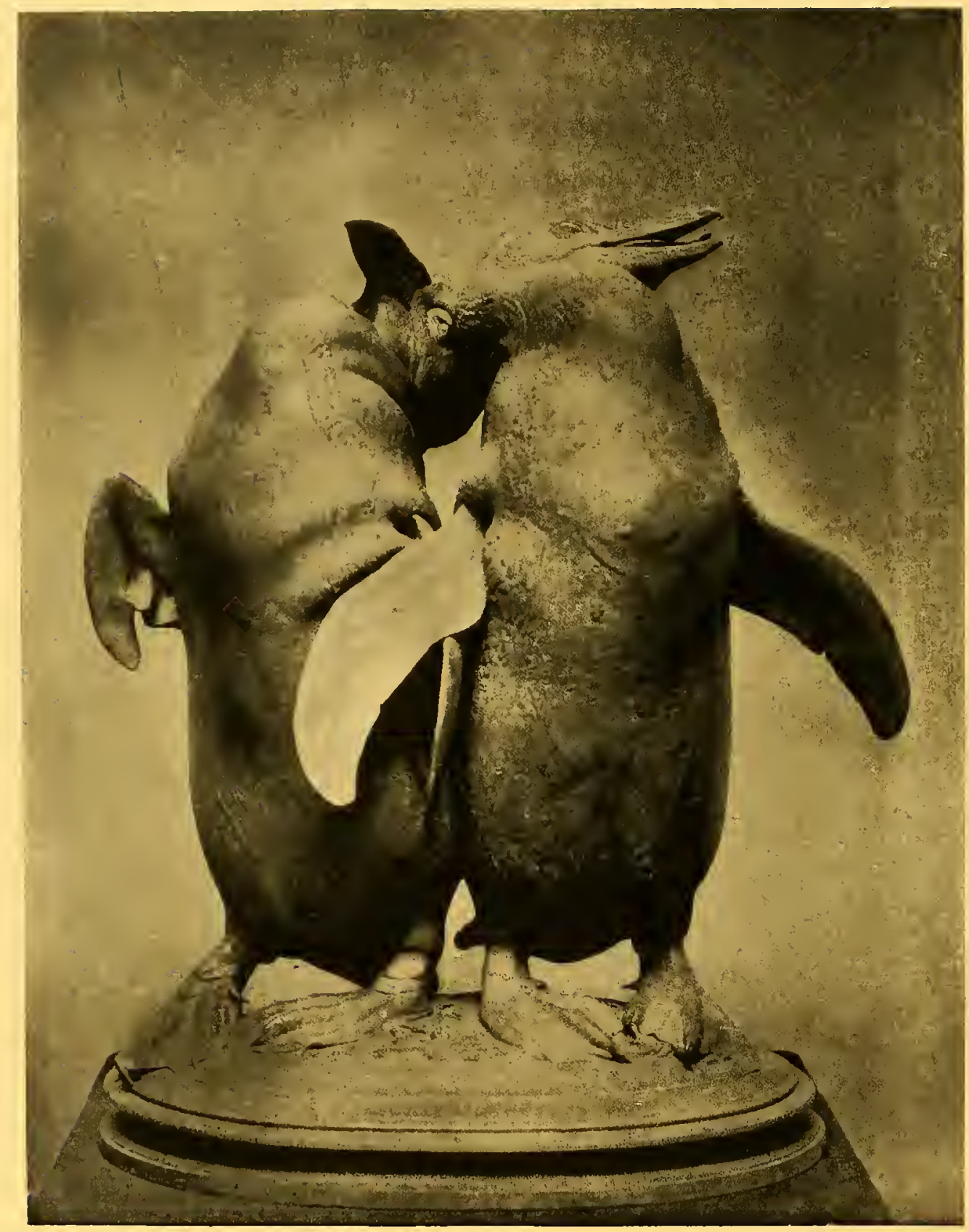

Penguins by Albert Laessle 


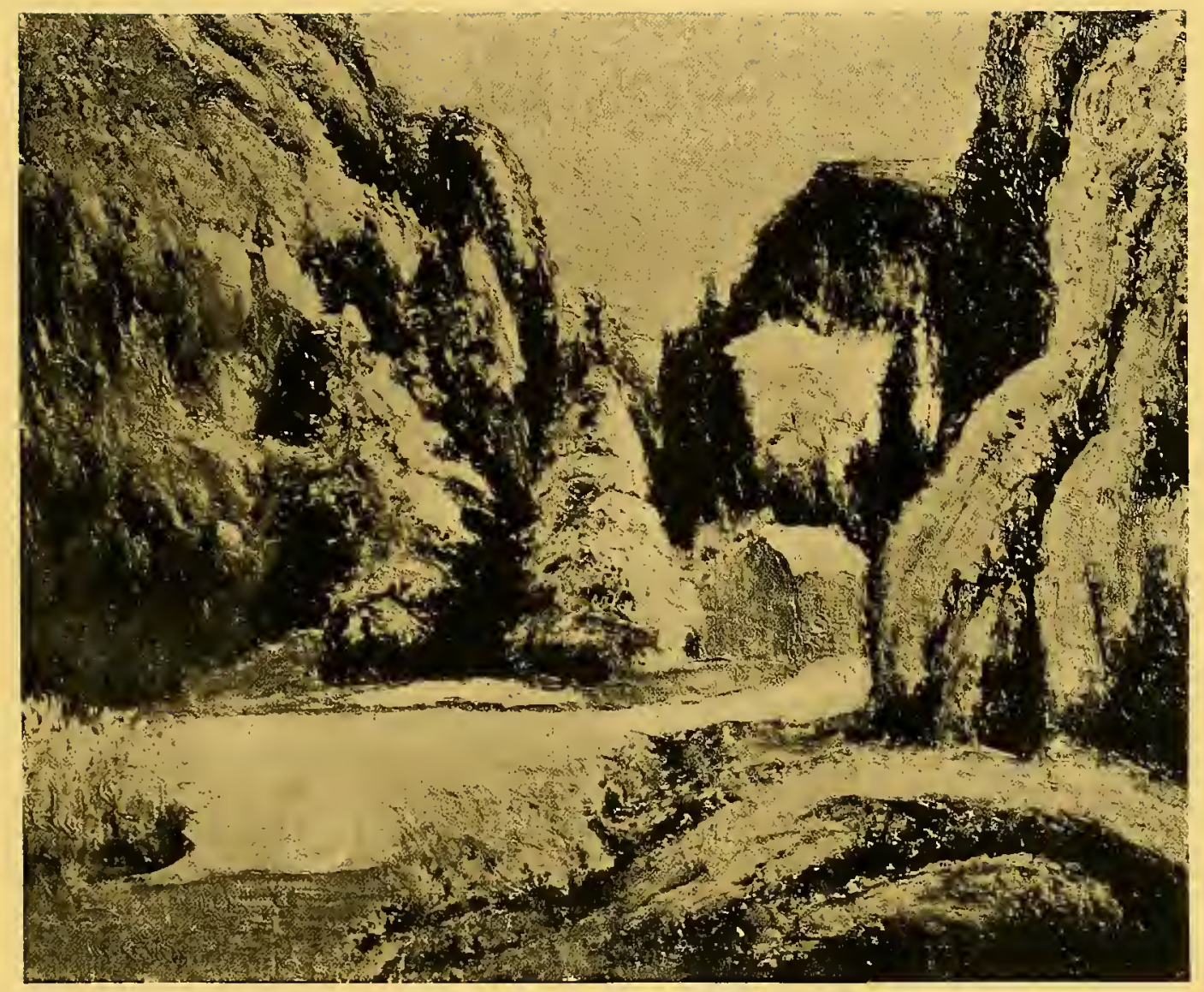

"Snowbound” by Ernest Lawson 


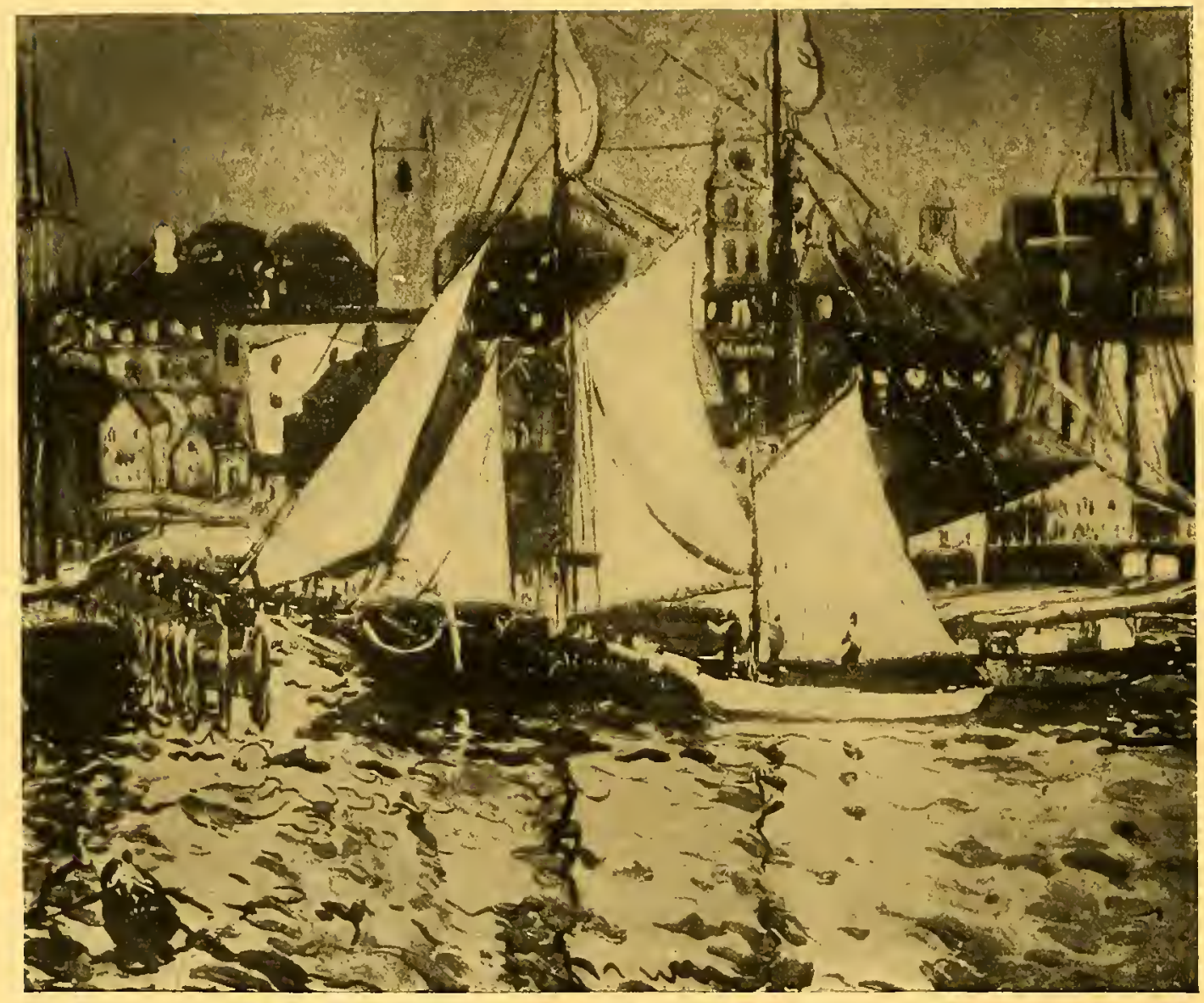

Fishing Smacks by Hayley Lever 


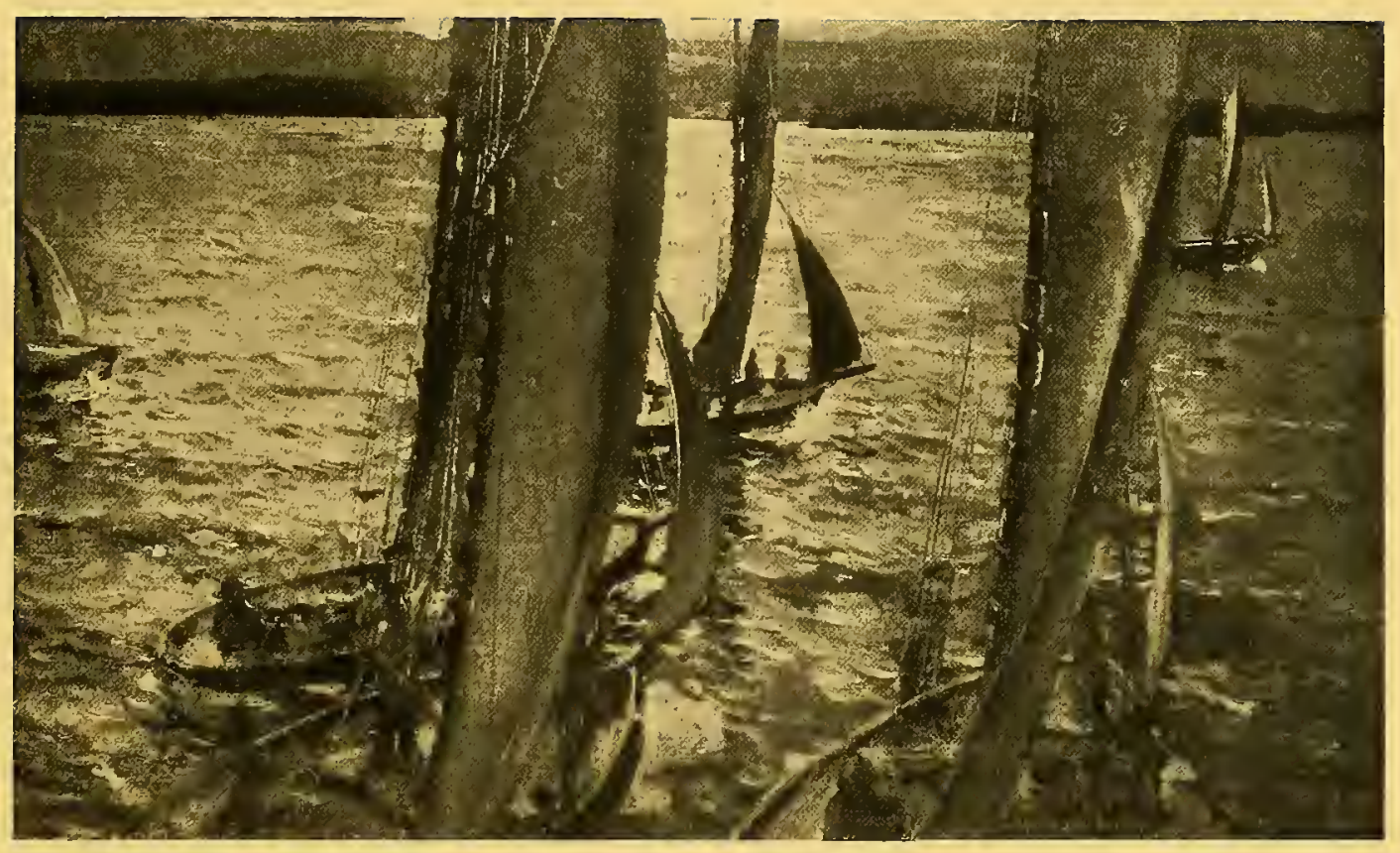

"Toilers of the Sea" by Jonas Lie 


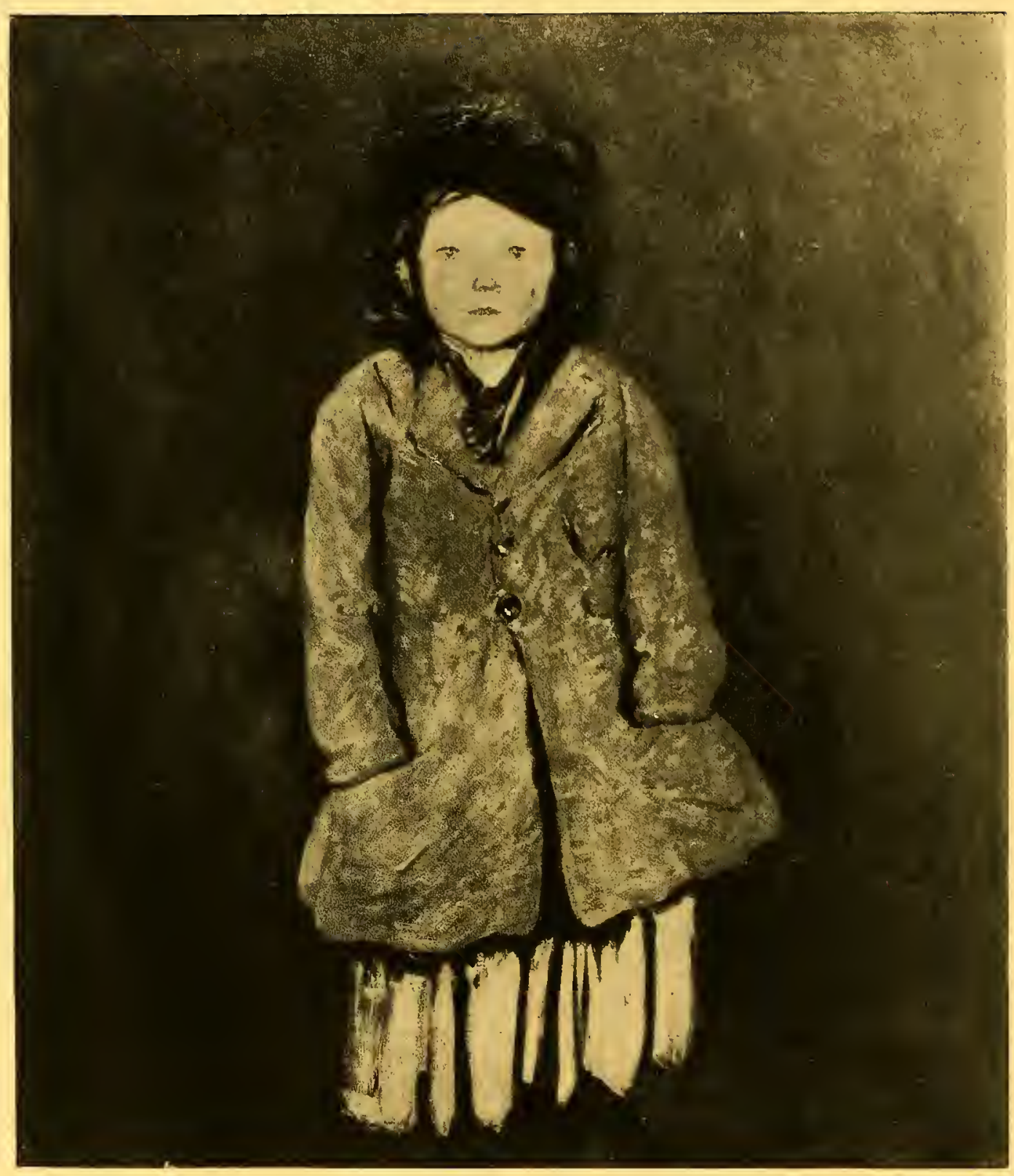

Lillie Williams by George Luks 


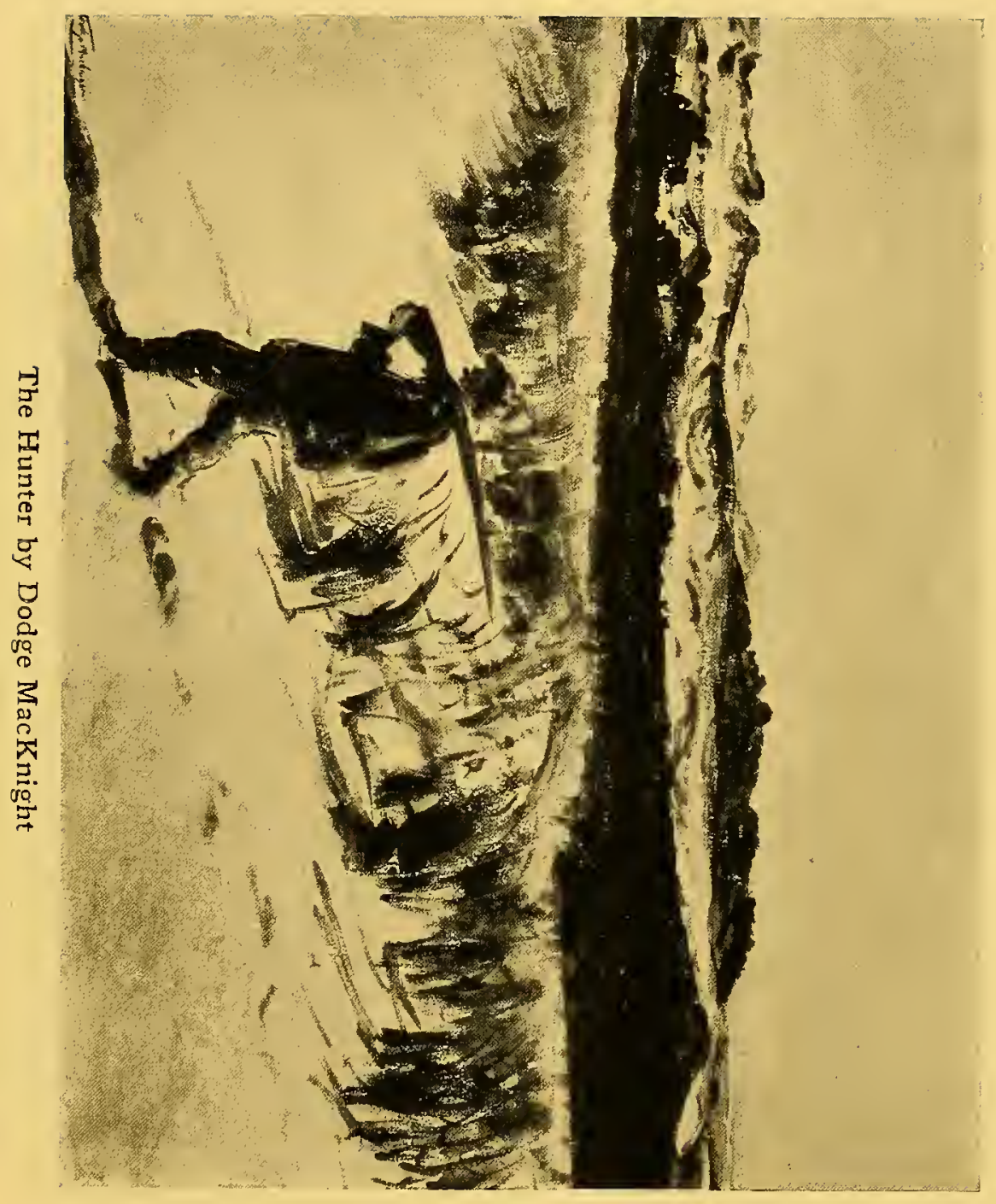




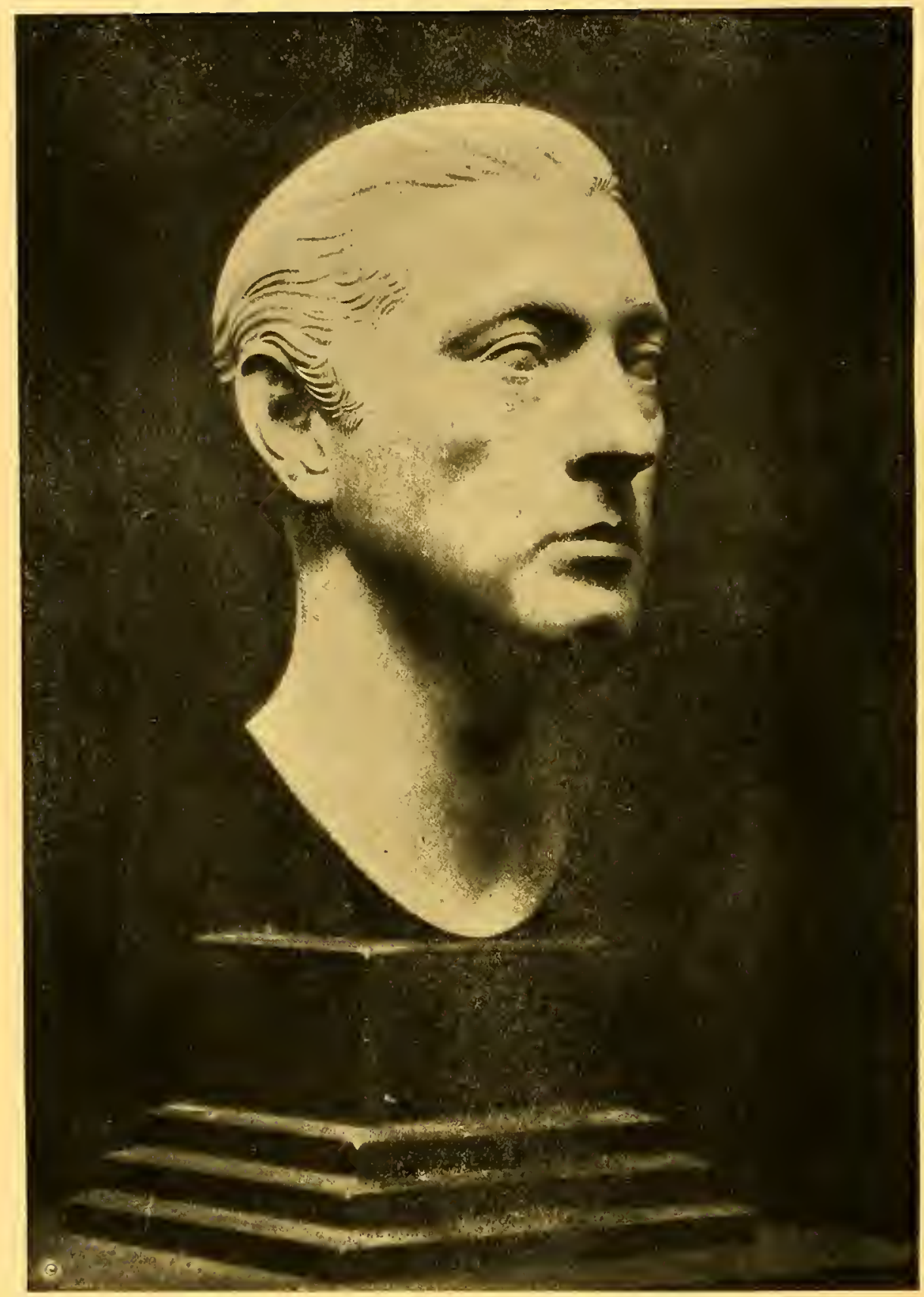

Portrait of John Barrymore by Paul Manship 


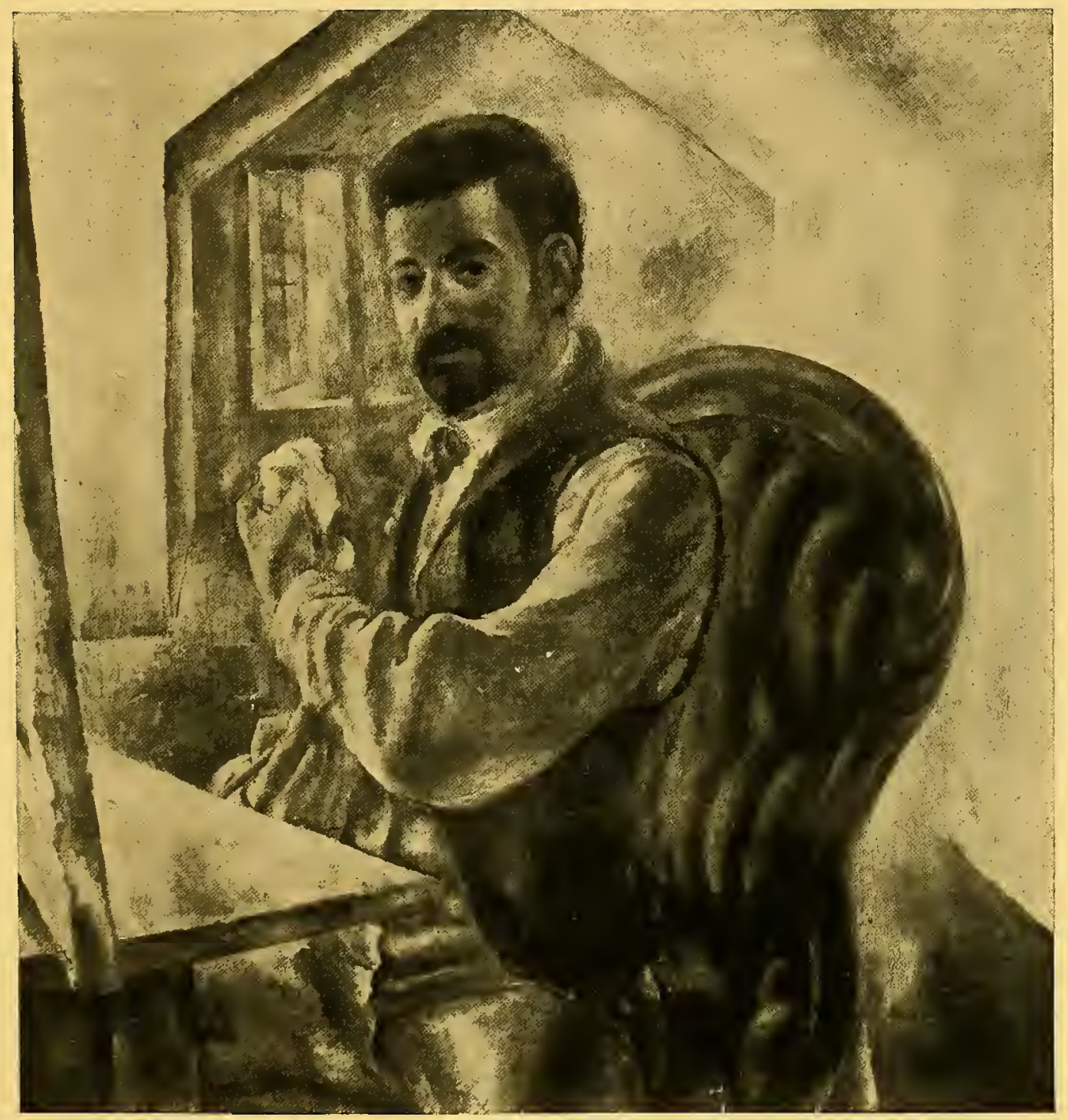

Portrait of a Painter by Henry L. McFee 


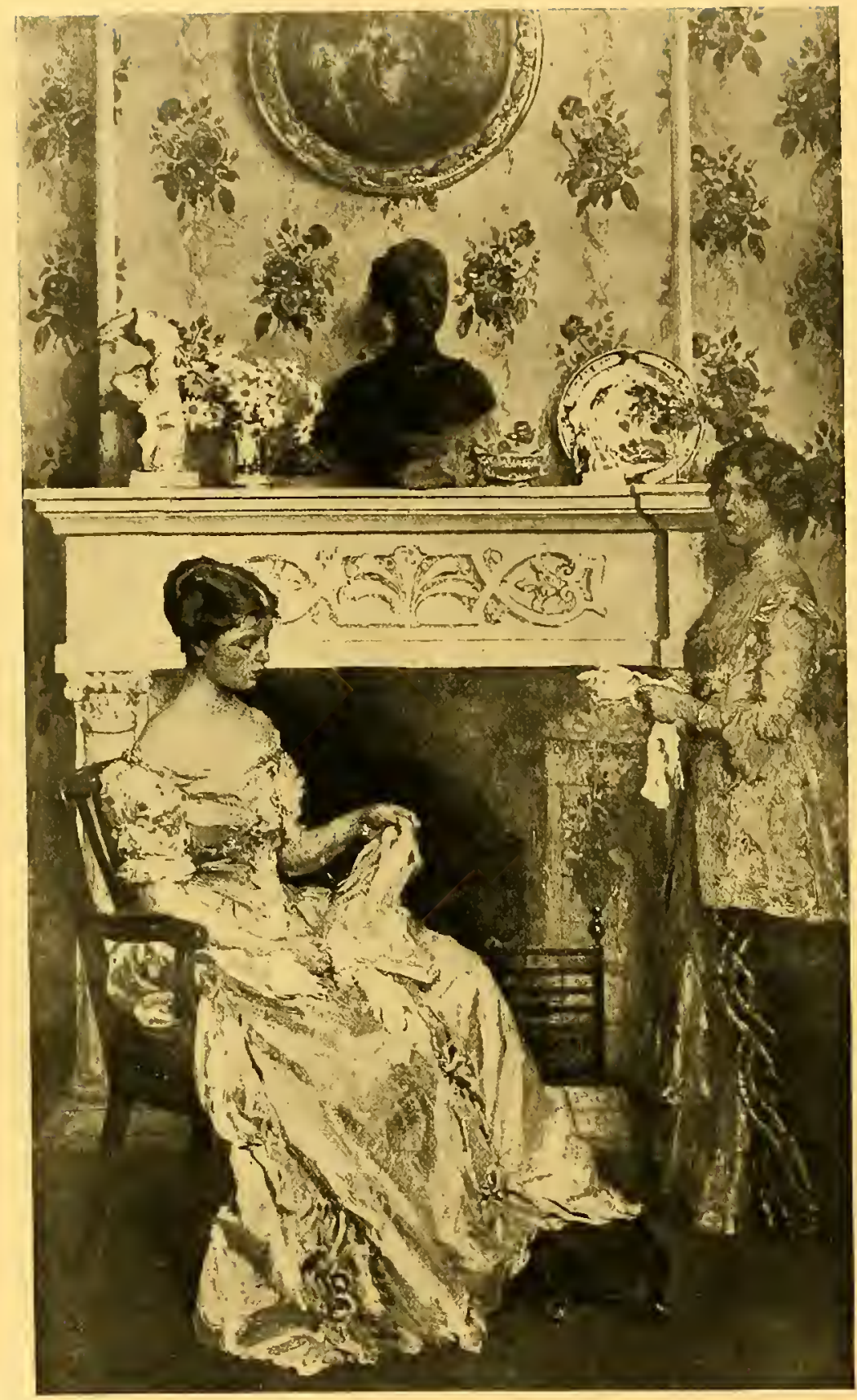

Winged Victory by Gari Melchers 


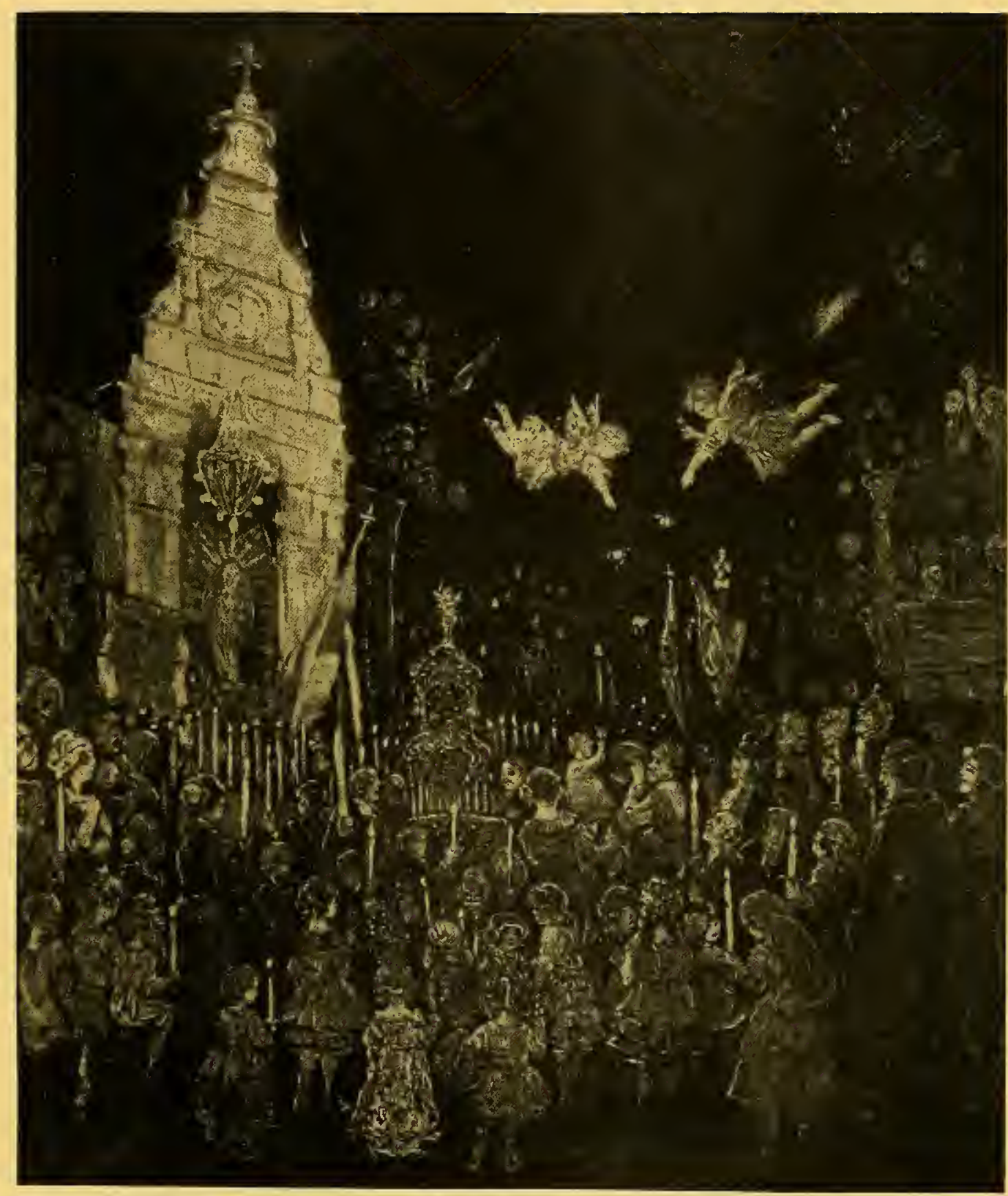

Angels of the Festa by Jerome Myers 


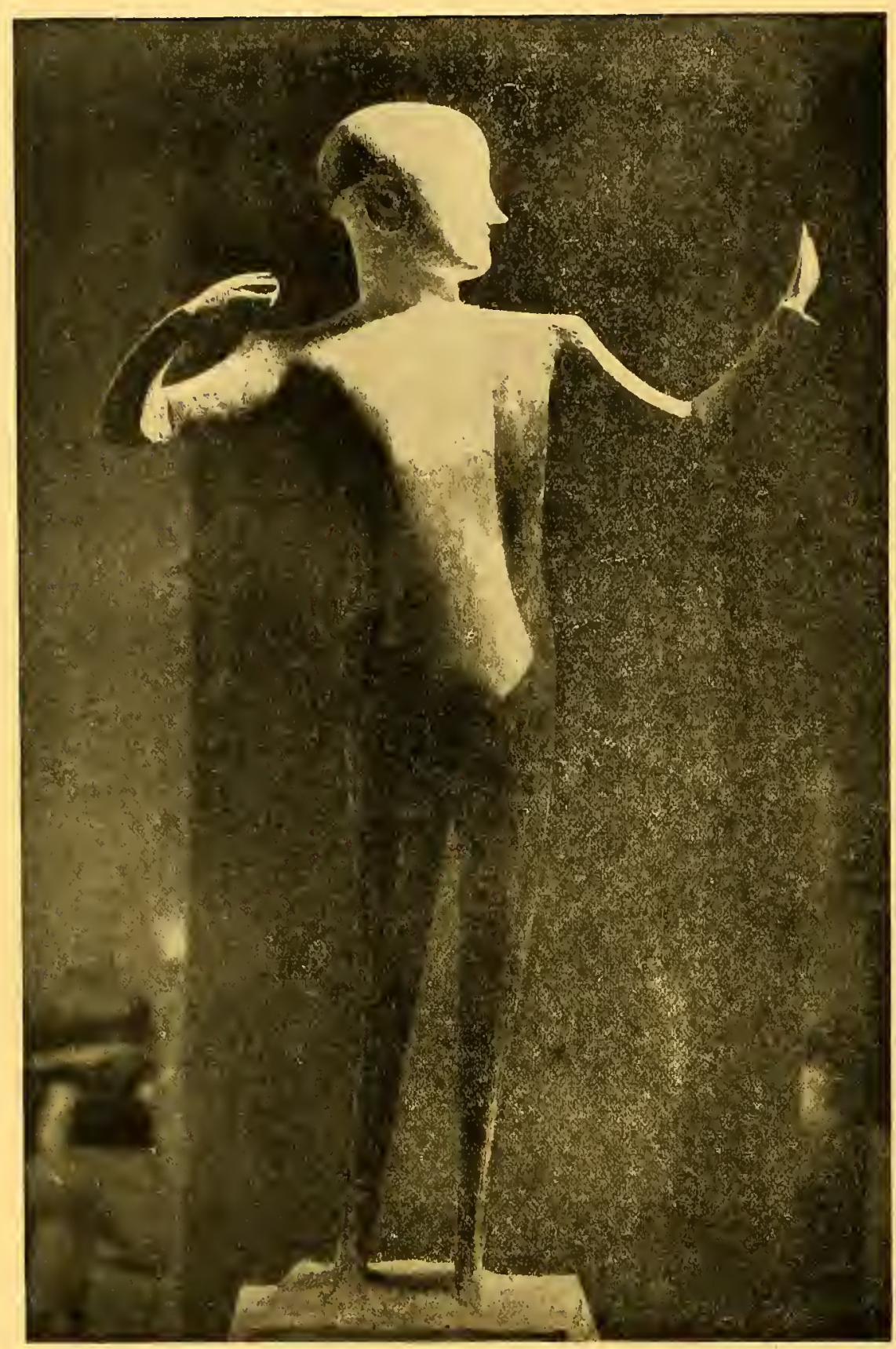

Chef d'orchestre by Elie Nadelman 


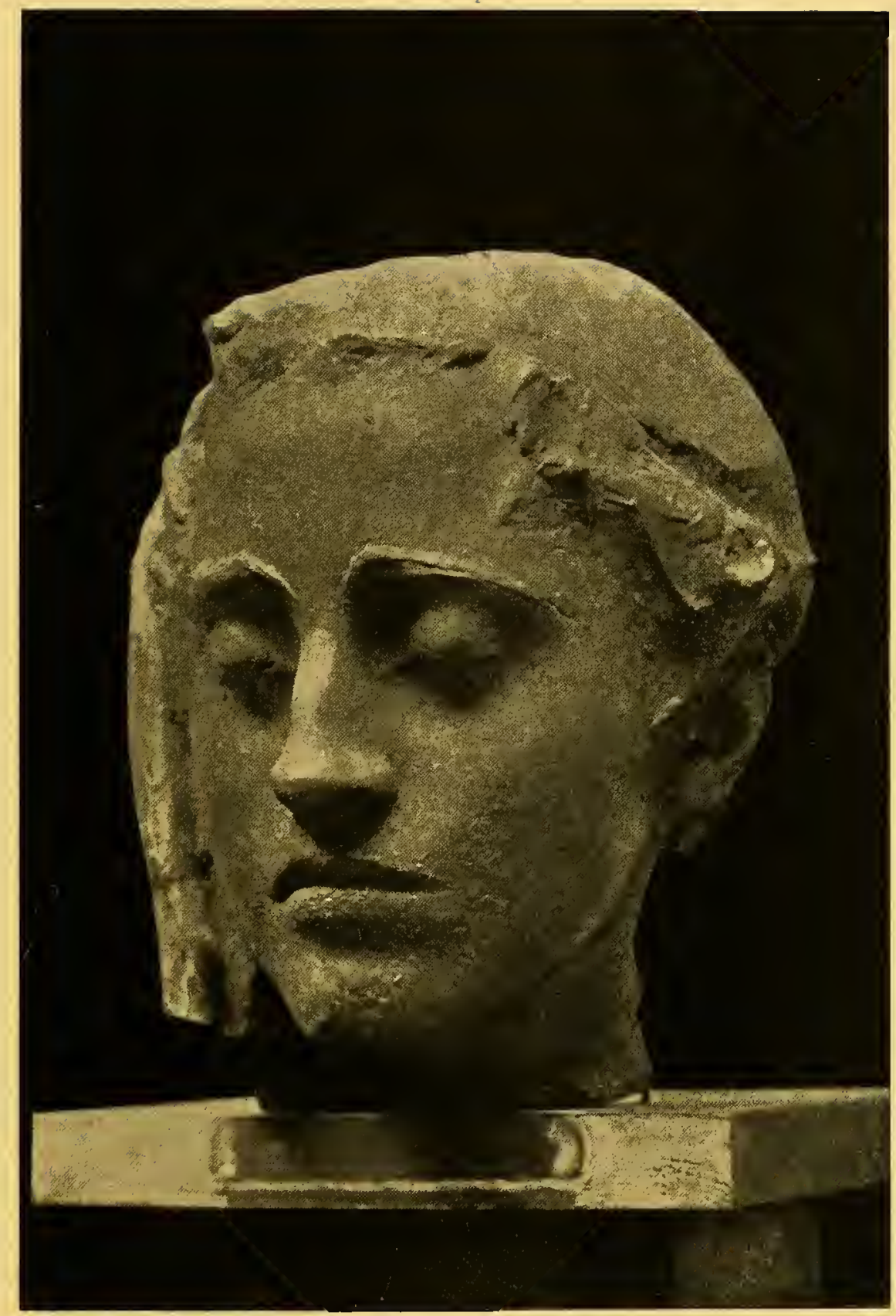

The Bronze Mask by Andrew O'Connor 


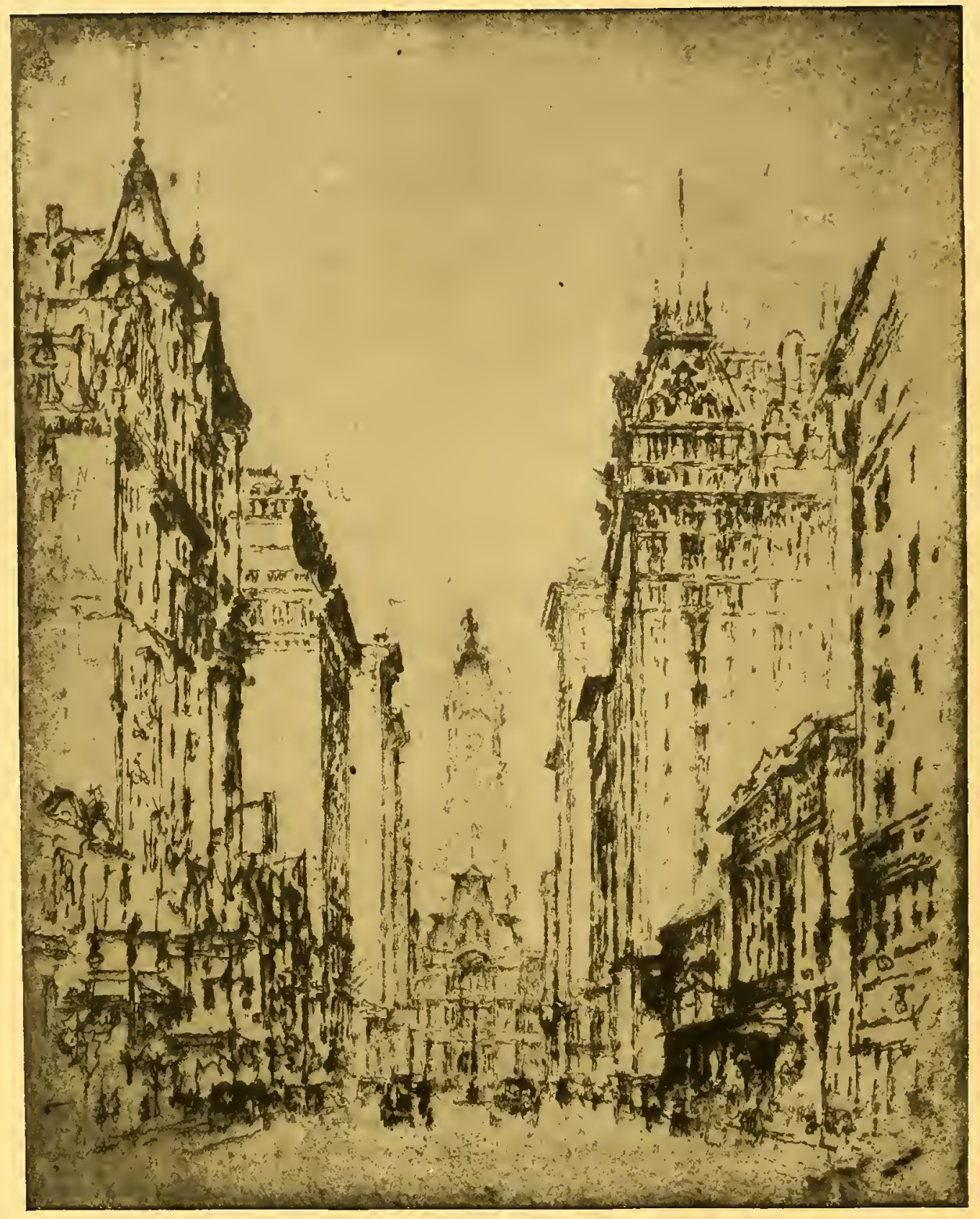

Broad Street, Philadelphia, by Joseph Pennell 


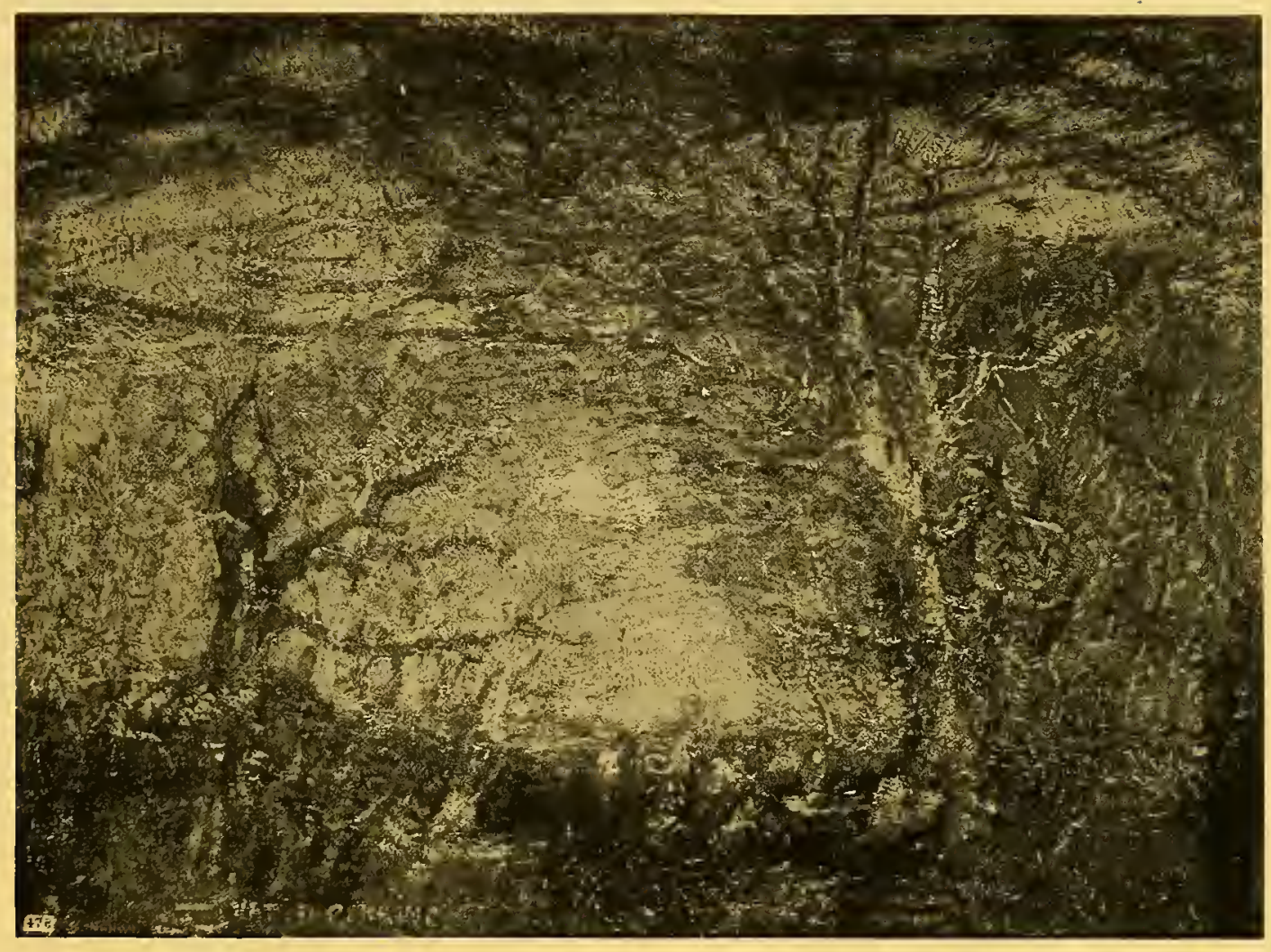

Autumn Landscape by Van D. Perrine 


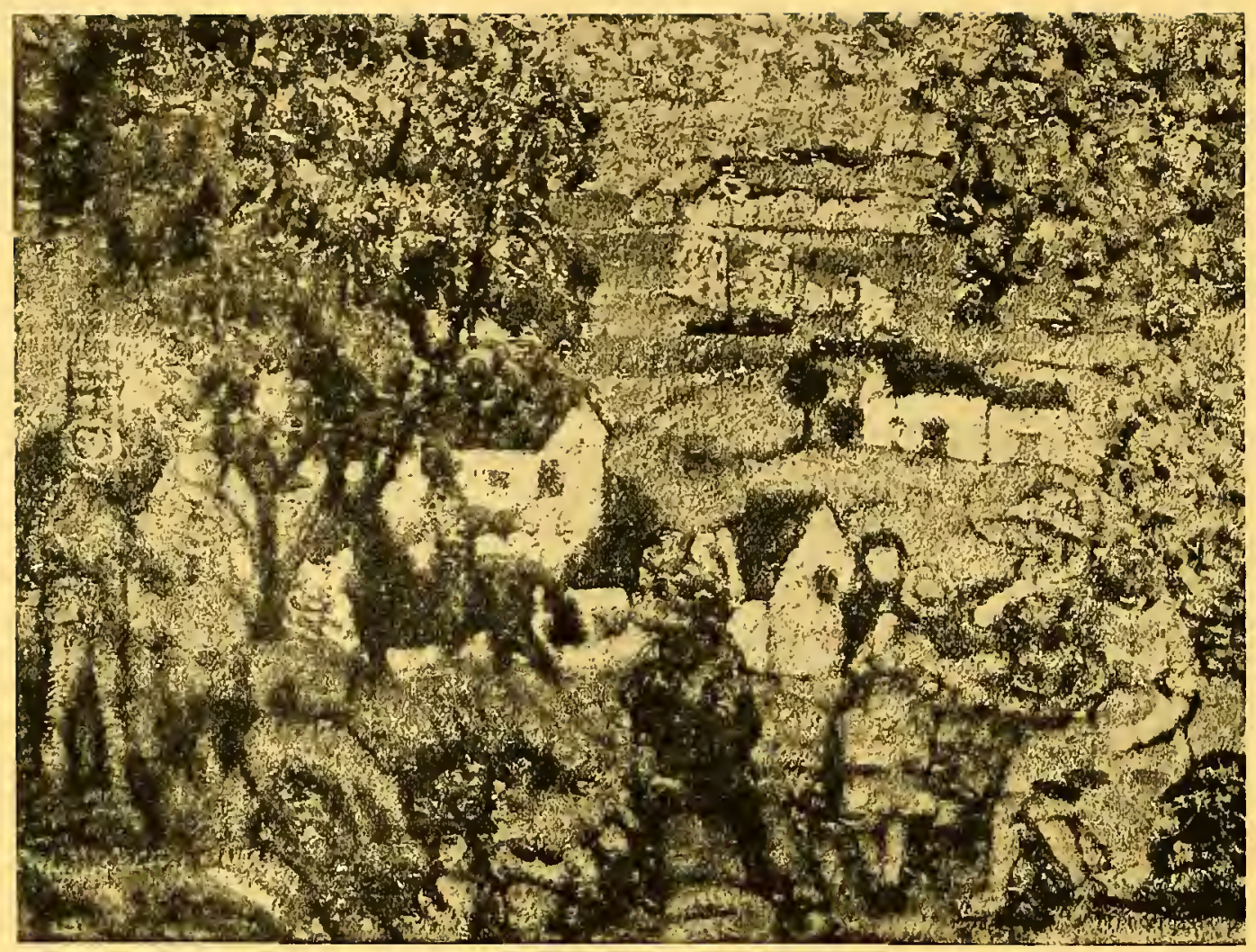

Entrance to Park by Maurice B. Prendergast 


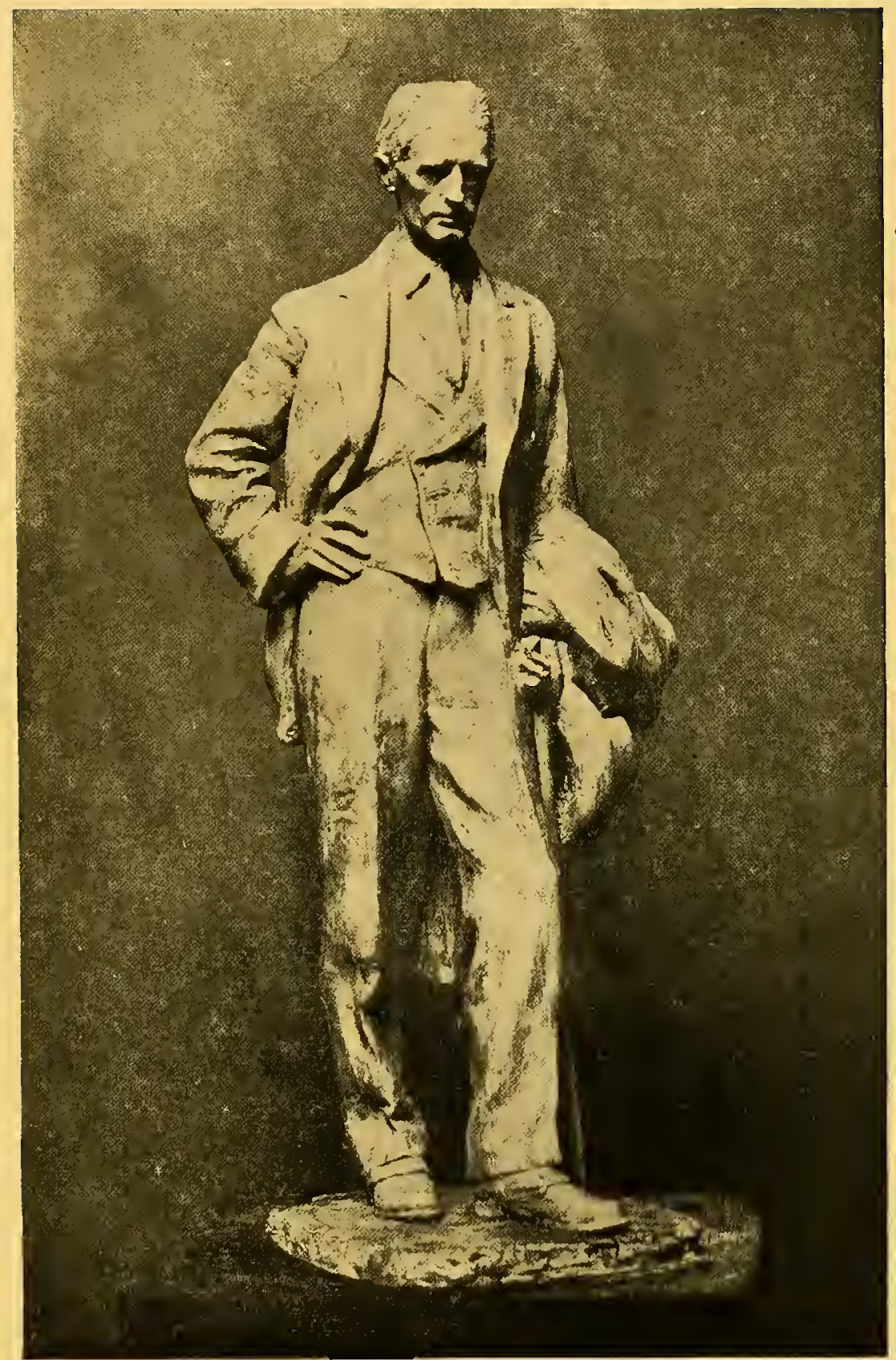

The Scotchman Abroad by Edmond T. Quinn 


\section{Henry Reinhardt \& Son Old Masters and Modern Paintings}

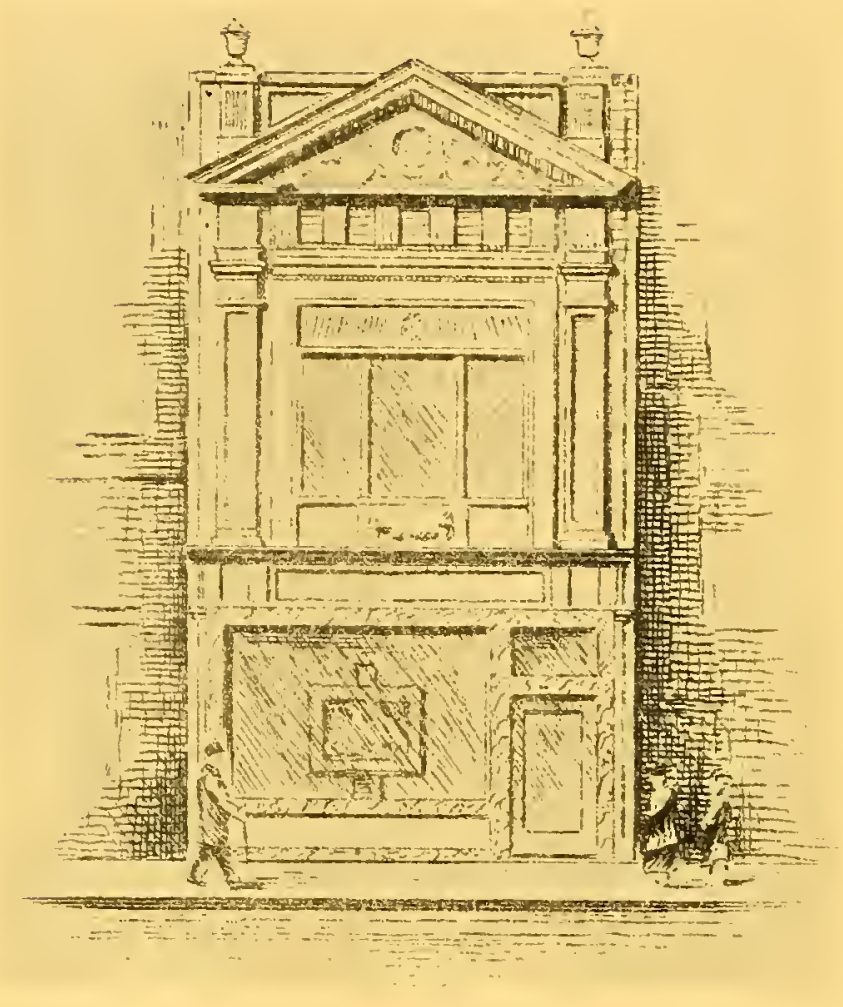

\section{After December I at Their New Galleries 606 Fifth Avenue}

PARIS

12 PLACE VENDOME
CHICAGO

536 S. MICHIGAN BOULEVARD 


\section{FOLSOM GALLERIES}

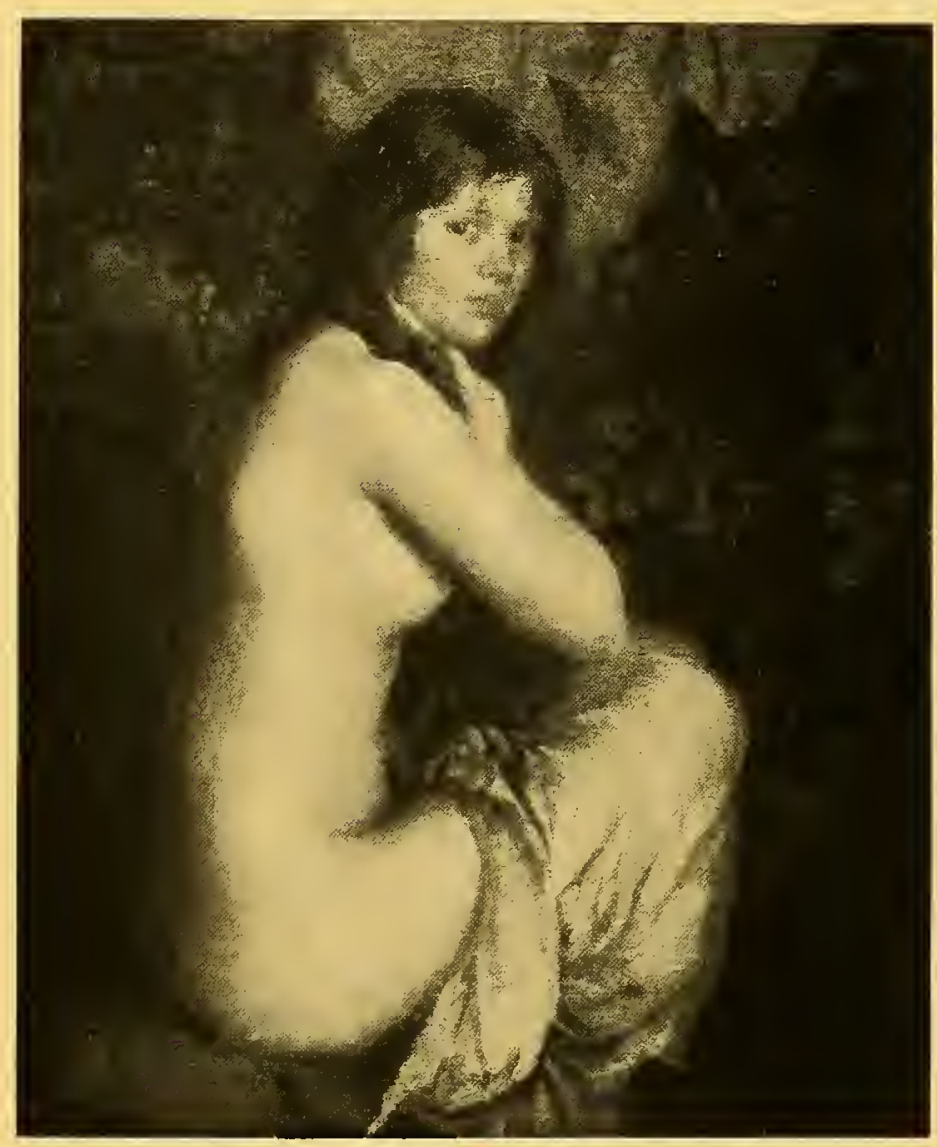

"NUDE

by Ivan Olinsky

\section{AMERICAN ART}

New Galleries at

104 West Fifty-Seventh Street, New York 


\section{H A N F S T A E N G L Galleries}

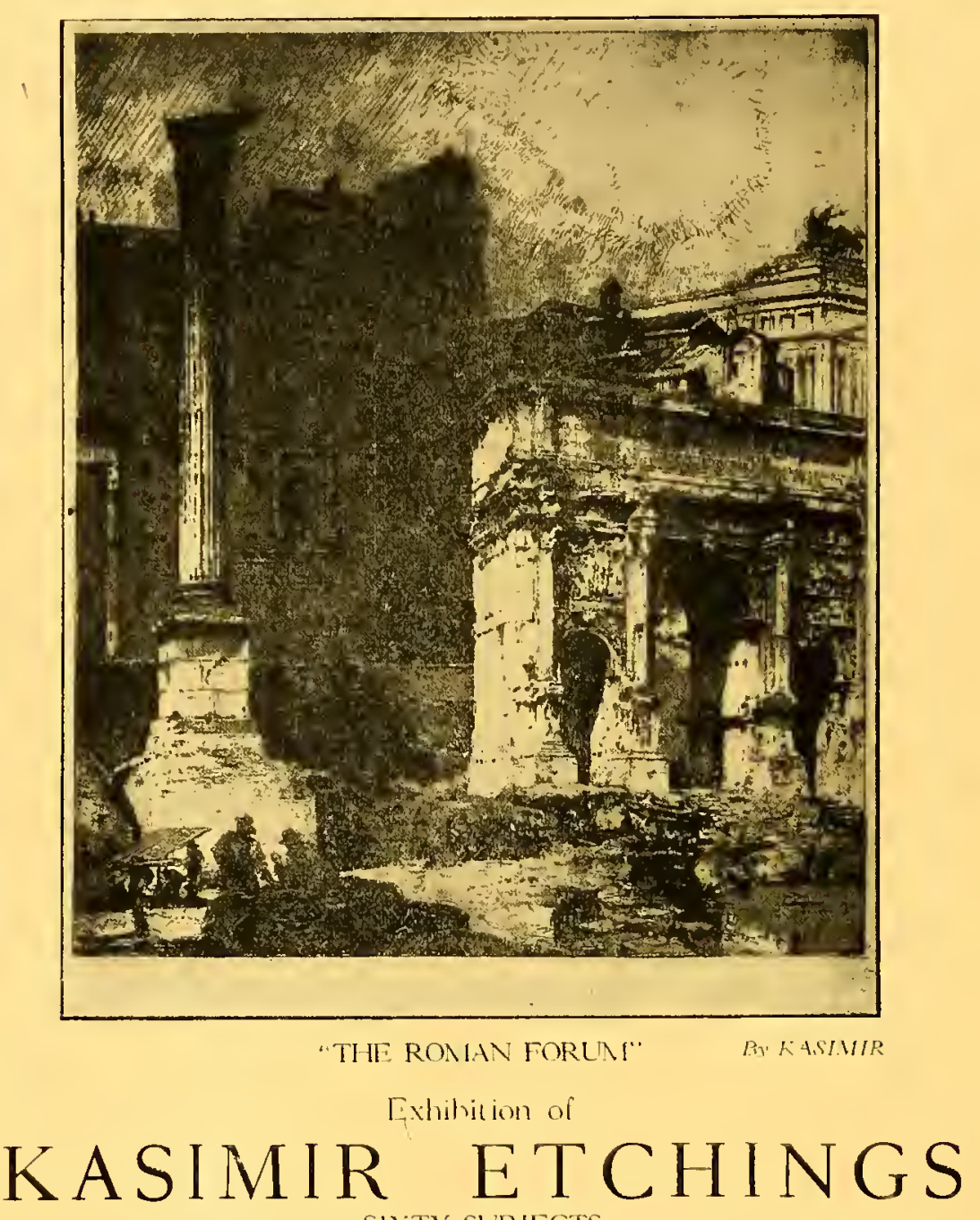

SIXTY SUBJECTS

ILILUSTRATED FOLDDER ON REQUEST

153 WEST 5,th ST., Opp. Carnegie Hall, NEII YORK 


\section{UDE N S I N

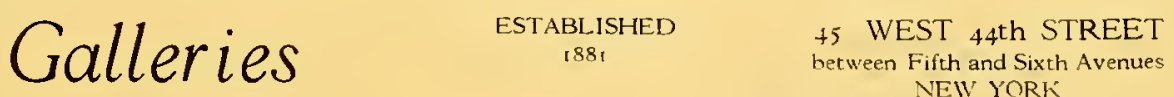 NEIV YORK}

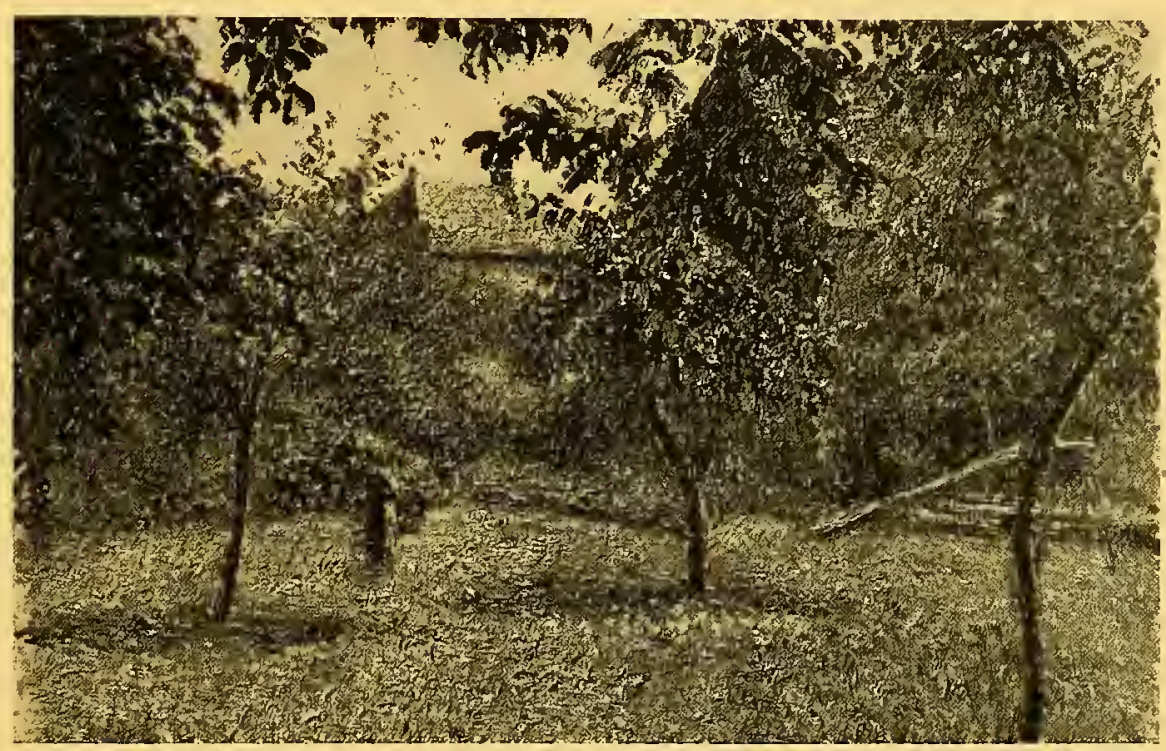

"Morning-The Farm," by Camille Pissaro

\section{INTERNATIONAL EXHIBITION}

PISSARO

SISLEY

LEBOURG

LE SIDANER

GUILLOMNET

CHARRETON
NIULERTT

MEYER

DE HOOG

$\overline{\text { NOW ON VIEW }}$
INNESS

IVYANT BLAKELOCK RITSCHEL DEWEY TIVACIITMAN 


\section{In the December \\ ARTS \& DECORATION}

\section{FORBES WATSON}

at his best in a scintillating critical review

of the current exhibitions in the art galleries.

\section{PROF. FRANK JEWETT MATHER} of Princeton, the great authority on primitives, discusses "Some Nativities" in his own delightful style.

IV. L. GEORGE, BRANDER MATTHEWS, AYMAR EMBURY II, DANIEL GREGORY MASON, E. HERMANN, are among the contributors to the Christmas number of the foremost magazine of all the arts.

ARTS \& DECORATION devotes more space to $\mathrm{A}_{\text {interesting and authoritative articles on paint- }}$ ings, and to their beautiful reproduction, than any other publication. WHENEVER, throughout the United States.
you find an actual or potential buyer of paintings, you find a reader of Arts \& Decoration.

\section{ARTS \& DECORATION}

The JOSEPH A. JUDD PUBLISHING CO., Inc. 25 West 43d Street, New York Ciry 


\section{Albert R. Louis \& Co.}

Importers

of

ANTIQUES

13 East 57th Street

NEIV

YORK

CITY

A small Italian cabinet of walnut, finely carved. The cabinet portion is lined with brocatelle of the 17 th Century. The cabinet is approximately of the sume period, the latter part of the Renaissance, and is of a wonderfill dark bronze-like color and patination. Height over all 5 ft. $\$ 1 / 2$ ins., wideh 2 ft 10 ins., depth 1 ft. 3 ins.

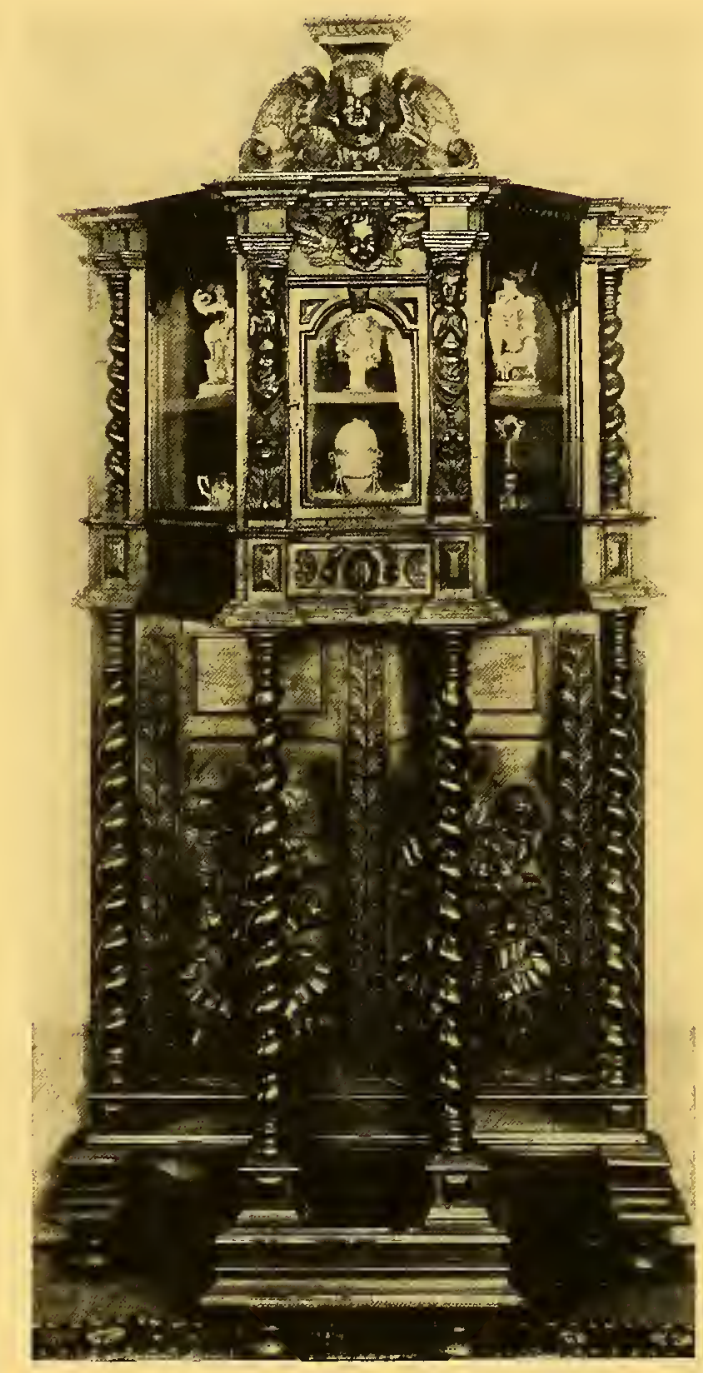

PHOTOGRAPHS GLADLY MAILED FOR YOUR APPROVAL 


\section{JOHN LEVY GALLERIES}

High Class

PAINTINGS

559 FIFTH AVENUE

NEW YORK

PARIS: 28 PLACE VENDOMIE

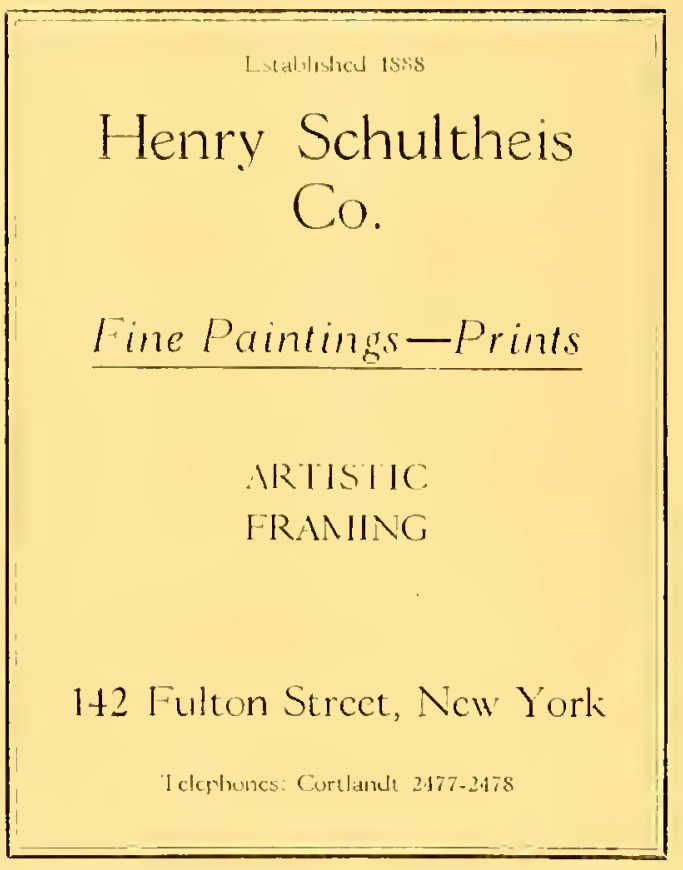

B A B C OCK

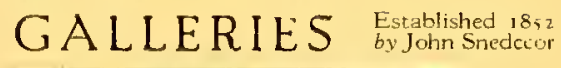

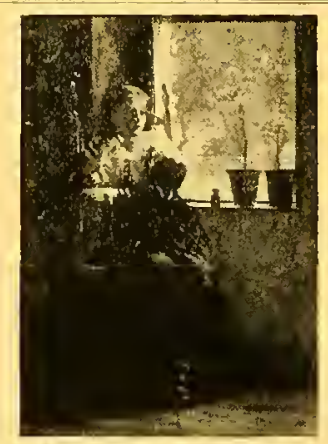

AT THE WINDOW

By Winslow Homer

MODERN PAINTINGS

in EAST 49th STREET, NEW YORK 


\section{SATINOVER GALLERIES}

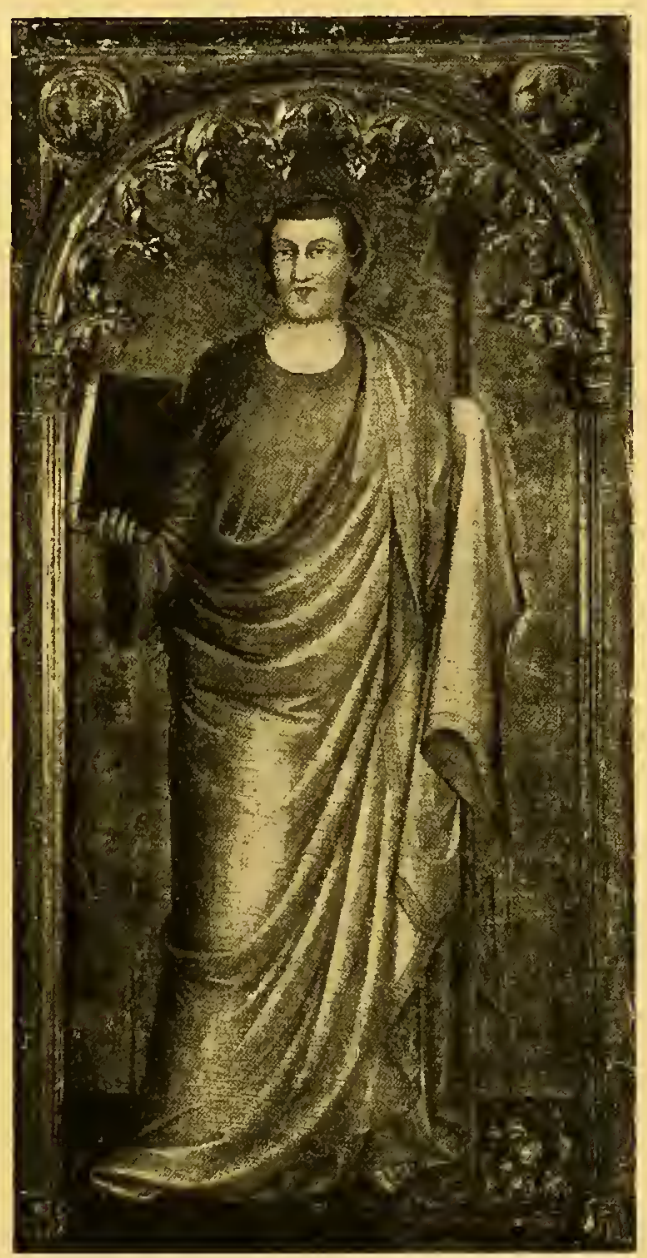

Selected Old Masters
27 West Fifty-Sixth Strect
NEW YORK 


\section{THE PALETTE ART CO.} E S T A E L I S H E D 1 \& $S 4$

327 Fifth Avenue Below 33rd Street New York City ARTISTS' MATERIALS

Picture Framing, Frames for Uil Paintings a Specialty

\section{W. S. BUDWORTH \& SON}

Established 1867

PAKERS, REMOIERS AND SHIPPERS

OF ITORKS OF ART

+24 West 52nd Street

NEIF YORK

Telephonc Connection, 120 Columbus

\section{PETER A. JULEY}

Photographer of Fine Arts

True Color Values Always

219 EAST 39th STREET

NEW YORK CITY

Telephone Vanderbilt 3494

ESTABLISHED 1886

INCORPORATED 1918

ARTISTS' PACKING \& SHIPPING CO.

H. W. MILLS, President and General Manager

PACKERS and SHIPPERS

MOVERS of WORKS of ART

139 WEST 54th STREET

NEW YORK 